\title{
The newspaper man: Michael Andrews and the art of painted collage
}

\author{
Mark Hallett
}

Aspects of Art Lecture, read 2 July 2019.

Abstract: This article focuses on an ambitious and complex pair of pictures painted by the prominent English artist Michael Andrews in the early 1960s, in which he juxtaposes a mass of visual elements taken from various photographic sources. Deer Park (1962) and All Night Long (1963-4) offer fascinating examples of what we might call painted collage. They also see Andrews testing out the possibilities of a new kind of painting of modern life, in which the forms of pictorial fragmentation and overlap associated with collage are brought to bear on the narratives and imagery of hedonistic party-going, as expressed in contemporary literature, journalism, photography and film.

Keywords: Collage, Michael Andrews, painting, photography, Deer Park, All Night Long.

Note on the author: Professor Mark Hallett is Director of Studies at the Paul Mellon Centre for Studies in British Art. He is the author of many publications on 18th-century British art, including The Spectacle of Difference: Graphic Satire in the Age of Hogarth (Yale University Press, 1999) and Reynolds: Portraiture in Action (Yale University Press, 2014). He has also been involved in curating numerous exhibitions, including Hogarth, held at Tate Britain in 2007, and The Great Spectacle: 250 Years of the Summer Exhibition, held at the Royal Academy in 2018. In recent years, he has also been pursuing research on modern and contemporary British art, and co-curated the display Vital Fragments: Nigel Henderson and the Art of Collage, which opened at Tate Britain in December 2019. 
This article has its beginnings in a holiday I took on the Yorkshire coast a few summers ago. During that holiday, I dropped into the gloriously ramshackle Clewlow bookshop, which is located in an old, converted church in the seaside town of Whitby. Rummaging through the shop's wares, my eye was caught by some rather battered copies of a journal from the 1960s, called Art and Literature, which was edited, amongst others, by the poet John Ashbery and the painter Rodrigo Moynihan. ${ }^{1}$ In particular, I was struck by the second issue of the journal, published in the summer of 1964, the elegantly tabulated cover of which, six lines down, featured the names of the artists Michael Andrews and Victor Willing. ${ }^{2}$ Intrigued, I opened the journal, looking for the feature on Andrews and Willing, and found that it took the form of an interview between the two men, illustrated by some examples of their recent paintings. ${ }^{3}$ One of the illustrations (Figure 1) was of Andrews' All Night Long, of 1963-4.

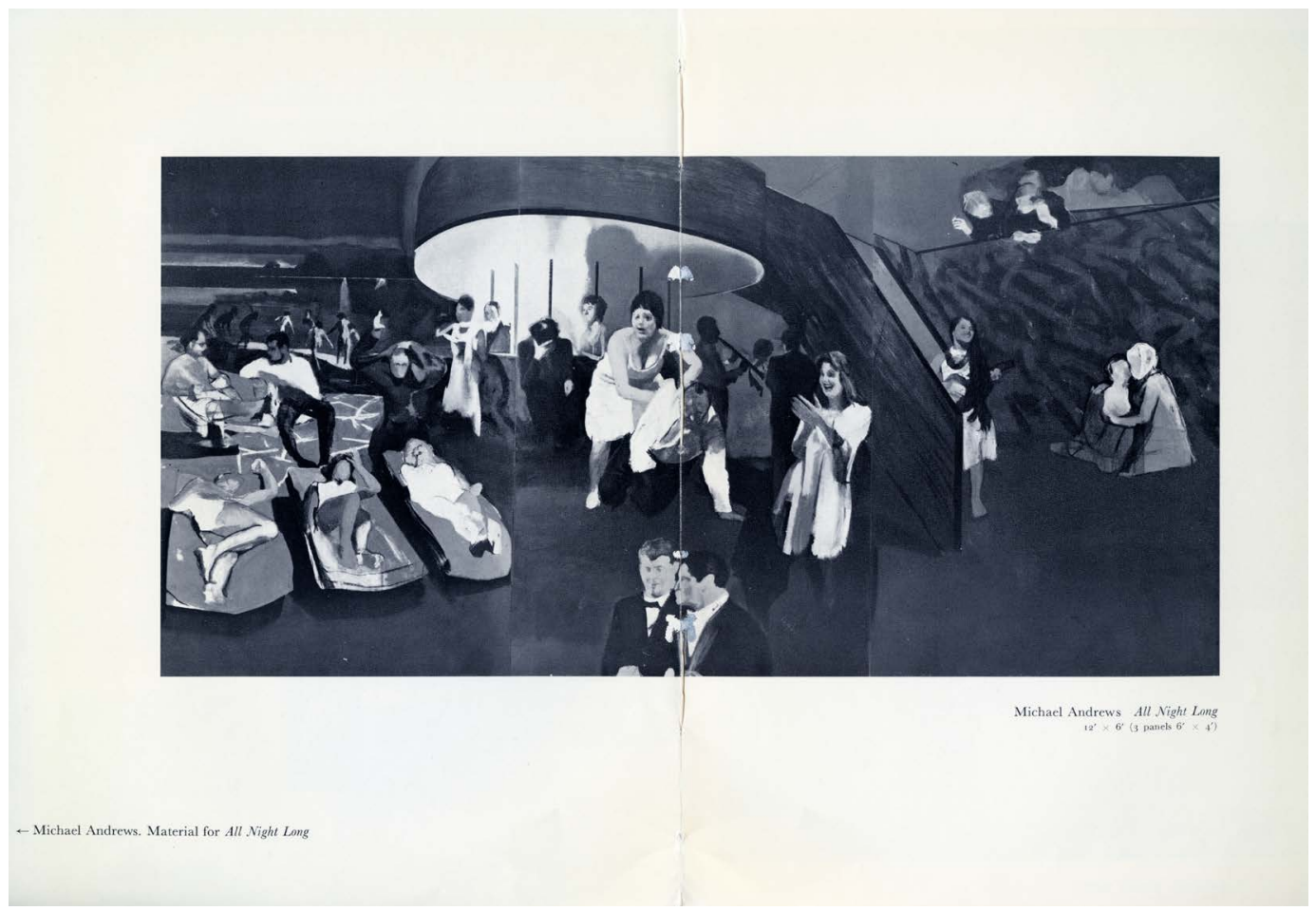

Figure 1. Michael Andrews. Reproduction of All Night Long, in Art and Literature: An International Review, volume 2, Summer 1964 (Lausanne, Switzerland: S.E.L.A., 1964).

${ }^{1}$ The full editorial board consisted of John Ashbury, Anne Dunn, Rodrigo Moynihan, and Sonia Orwell. ${ }^{2}$ Art and Literature: An International Review, Summer 1964 (Paris).

${ }^{3}$ Michael Andrews \& Victor Willing (1964). 

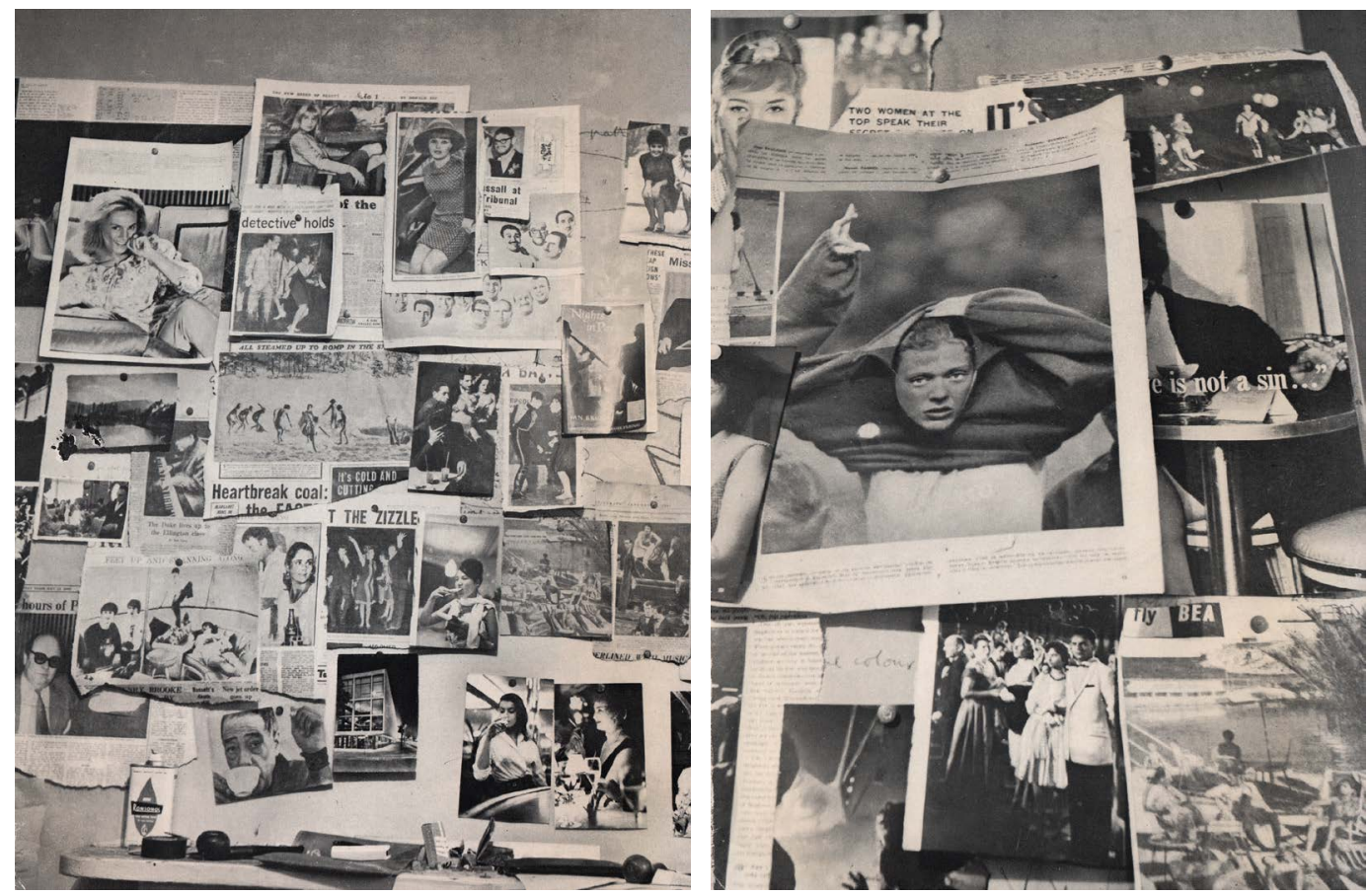

Figure 2. Assemblage of materials in Michael Figure 3. Assemblage of materials in Michael Andrews' Islington studio, in Art and Literature: An Andrews' Islington studio, in Art and Literature: International Review, volume 2, Summer 1964 An International Review, volume 2, Summer 1964 (Lausanne, Switzerland: S.E.L.A., 1964): p. 55. (Lausanne, Switzerland: S.E.L.A., 1964): p. 53.

I had seen and been hugely impressed by All Night Long on a trip to Australia that I had taken in a previous year: the painting is housed at the National Gallery of Victoria, in Melbourne. But what especially interested me, on finding the black and white reproduction of the work in Art and Literature, was the arrowed caption whichwith the words 'Material for All Night Long' - directed the reader back to a trio of accompanying illustrations found on the journal's previous three pages. The first (Figure 2) showed a crowded assemblage of photographs, seemingly cut out from newspapers, magazines, and picture-books, and pinned in overlapping layers onto a bare wall. This assemblage, I happened to notice, surmounted a cluttered mantlepiece featuring two pipes and a tin of Ronsonol lighter fluid. The second and third illustrations, meanwhile, offered close-up views of this same collection of faces, figures, and fragmented headlines (Figures $3 \& 4$ ).

It took only a few seconds to begin seeing the connection between this cluster of images and All Night Long itself: tracking between one of the close-ups (see Figure 4) and the illustration of the painting allows us, too, to start recognising the ways that Andrews adapted the motifs of the pinned-up photographs, or at least some of 


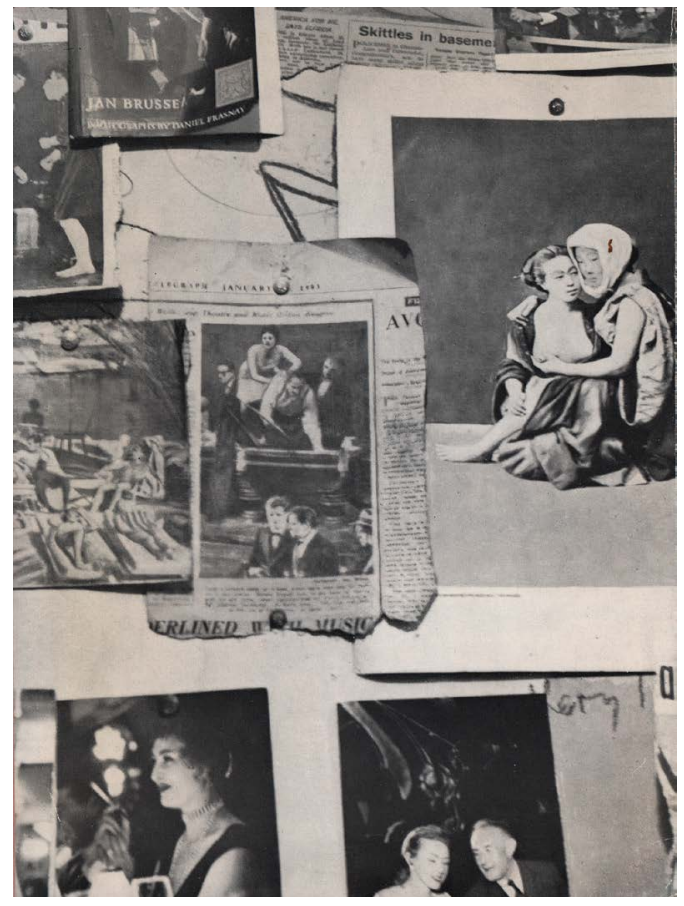

Figure 4. Assemblage of materials in Michael Andrews' Islington studio, in Art and Literature: An International Review, volume 2, Summer 1964 (Lausanne, Switzerland: S.E.L.A., 1964): p. 54.

them, within his painting: thus, tracking left to right, we find that a truncated photograph of sunbathers has been translated into the image of similarly sprawling sun-seekers on the painting's left; that a blurred newspaper photograph of two dinner-jacketed men and what seems to be a stumbling man and woman, has been transplanted into the painting's centre; and that a larger, older photograph of two intimately coupled women in Japanese dress has been used as the basis for the similarly embracing figures found on the painting's right.

Intrigued by these correspondences, and thinking that I would like to find out more about all of this one day, I bought the journal, tucked it away in my rucksack, and returned to my holiday. On receiving the British Academy's invitation to give the 2019 Aspects of Art lecture, on which this article is based, I decided to use my second-hand copy of Art and Literature as the starting point for an exploration into the contents and character of both All Night Long and its immediate predecessor, The Deer Park, which was executed in the last weeks of 1962. In pursuing this form of enquiry, I found myself recovering an especially striking form of painted collage, produced in the early 1960s by an artist-Michael Andrews-who, though much admired by his more celebrated artistic contemporaries and by a clutch of arthistorians, dealers, and collectors, still seems relatively unfamiliar and understudied.

A photograph of Andrews (Figure 5) in his rented Islington studio, taken by John Deakin early in 1963, will serve to introduce the artist at precisely the time he was painting the early stages of All Night Long. It also confirms the importance of photography, and of newsprint in general, to his self-presentation in this period. Here, the artist rests his arms on the same mantelpiece that is found in the Art and Literature 


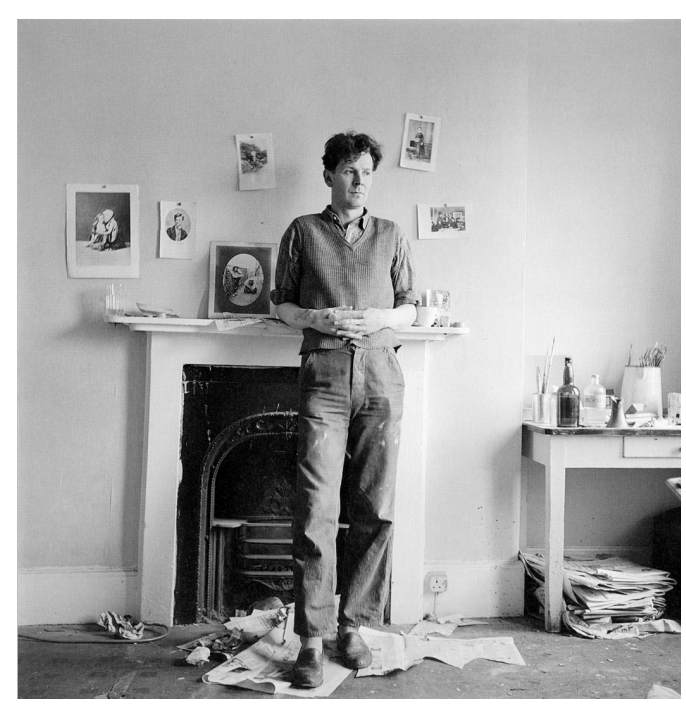

Figure 5. John Deakin, Michael Andrews in his studio, photograph, 1963. (C) John Deakin / John Deakin Archive / Bridgeman Images. illustration, this time surmounted by an earlier, rather sparser, assemblage of photographic cut-outs; it already includes that Japanese photograph of two embracing women that we have just been looking at. In Deakin's studiously composed portrait, Andrews is framed not only by these photographs, and by the tilted edges of the fireplace surround, but by the ripped, crumpled, and outspread newspaper pages that lie at his feet. These pages, offshoots of the pile of newspapers stuffed under the nearby table, might be understood simply as the everyday accessories of Andrews' studio, used to keep paintbrushes clean or to light his fire during the winter. However, just as in fire dung the whter. How like a jurland the case of the photographs that encircle the artist's head and shoulders like a garland, they can also be interpreted as a kind of pictorial clue or key, and as a pointer to the fact that, by 1963, such materials had become one of the foundational elements of a new form of collage-based practice on his part.

This type of practice seems to have had its origins in a crippling form of creative slowdown experienced by the artist in the summer of the previous year. In July 1962, Andrews, with an exhibition at the Lessore Gallery booked in for the coming November, was still trying to bring to conclusion a large group-portrait of his family (Figure 6), upon which he had been working for the previous two years. He was also trying to complete a second large-scale painting for the same exhibition (Figure 7), this time featuring a gathering of his London friends and acquaintances - including Lucian Freud and Francis Bacon - at the Colony Room in Soho, one of the haunts of artistic bohemia in the period.

Completing both of these pictures was, however, proving exceptionally difficult for the artist. Over the previous decade, Andrews had evolved a slow and laborious method of working, which was marked by the preparation of numerous drawn and painted studies, by an exacting attentiveness to the living model and by the painstaking application of paint, all of which had been promoted by his old teacher, William Coldstream, at the Slade School of Art. Though this mode of painting continued to serve him well when it came to his single-figure portraits, Andrews was finding it increasingly counterproductive for his large multi-figural pieces, which were taking what seemed to his eyes, and to those of his long-suffering dealer, Helen Lessore, an 


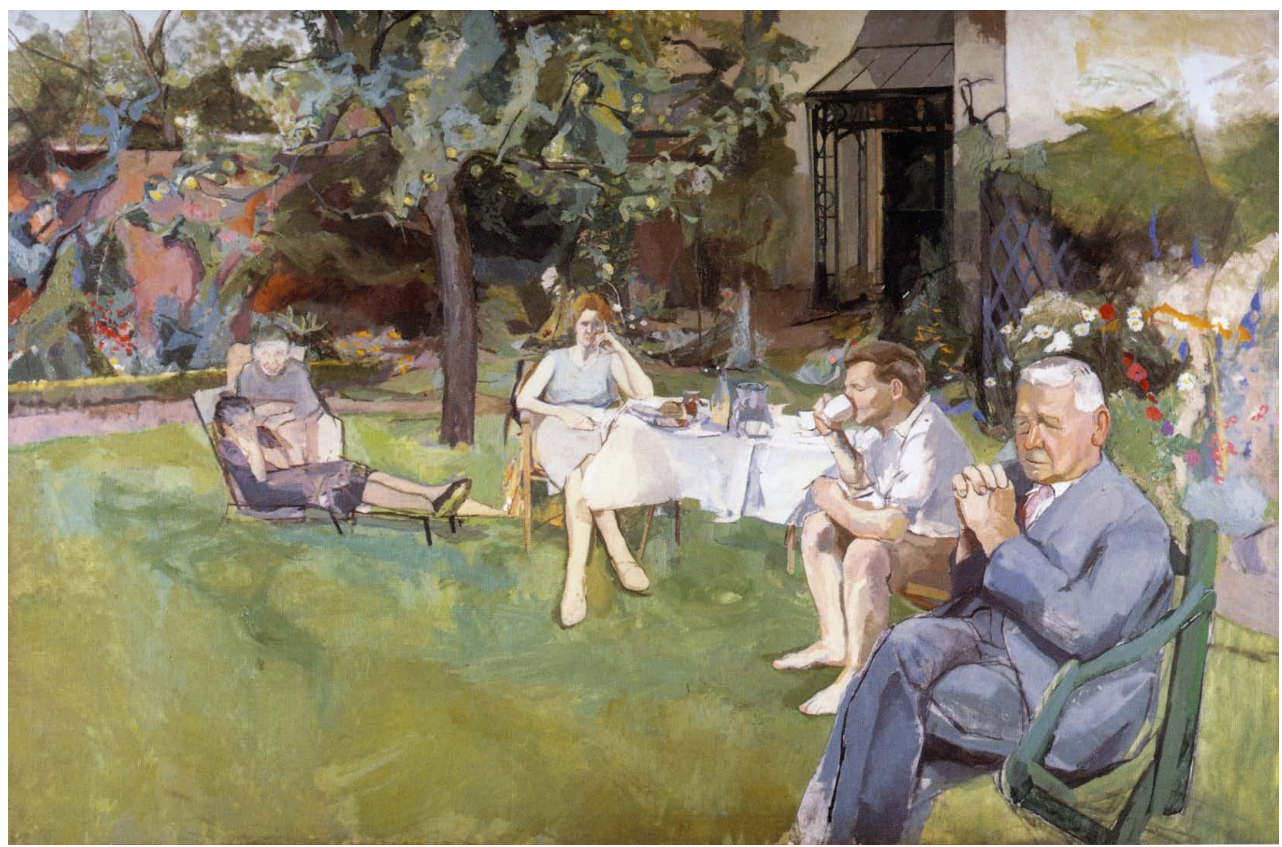

Figure 6. Michael Andrews, The Family in the Garden, 1960-62, oil on canvas, $198 \times 300 \mathrm{~cm}$. (C) The estate of Michael Andrews / Calouste Gulbenkian Foundation.

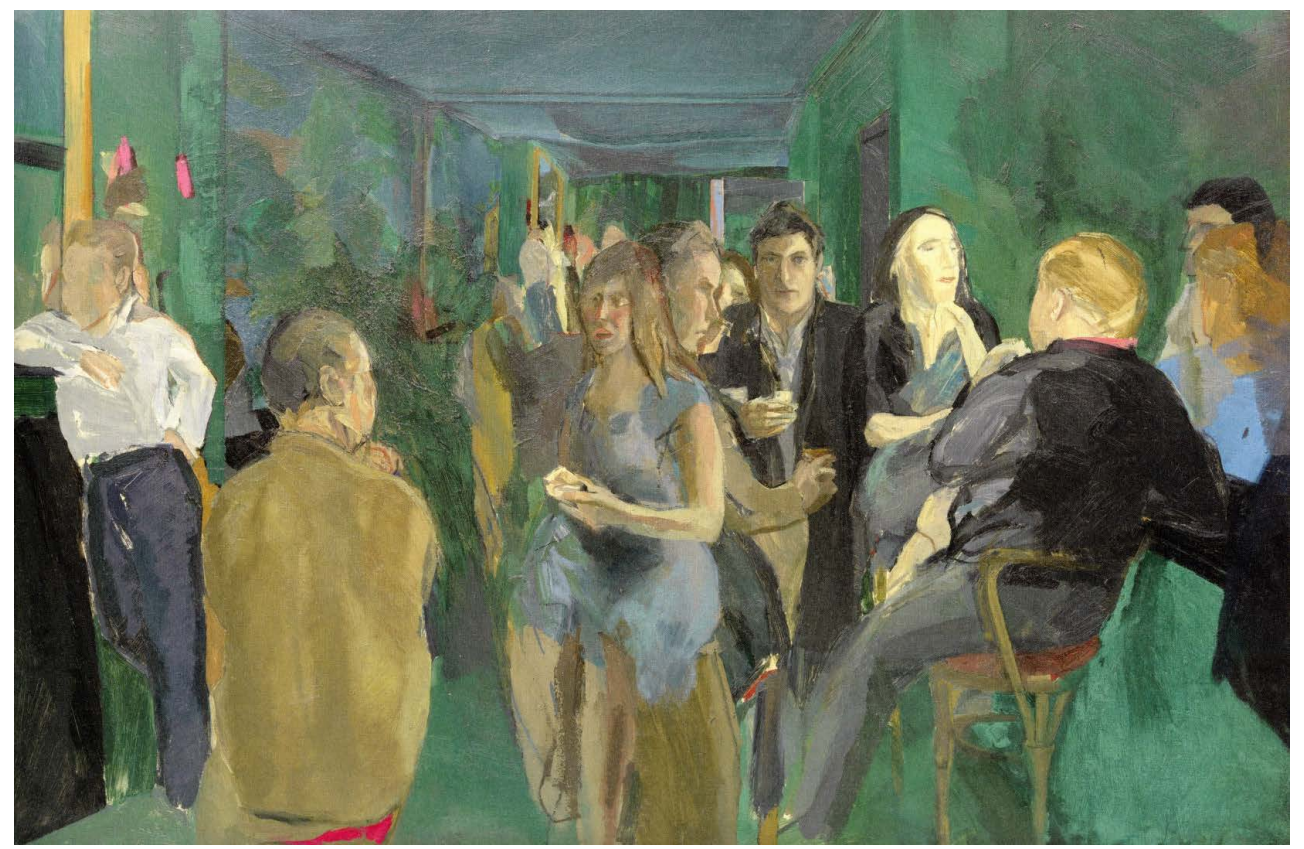

Figure 7. Michael Andrews, The Colony Room I, 1962, oil on board, $122 \times 183 \mathrm{~cm}$. (C) The estate of Michael Andrews / Pallant House Gallery, Chichester, Wilson Gift through the Art Fund 2006. 
age to complete, and which he felt were always in danger of becoming clogged with fussiness and overwork.

In a later interview, Andrews described himself breaking out of this impasse in decisive fashion: noting that 'the Colony Room painting had gone on for at least a year', and that he had been 'painting very slowly', he remembered that he 'suddenly wanted to paint in a really cursive running style'. ${ }^{4}$ His diary entries from 1962 help fill out the story. On 9 July, for instance, we find Andrews asking himself why he doesn't 'paint in a faster way'; and just three days later, he starts mulling upon a new way of planning and producing a picture, which might circumvent the difficulties he was currently facing: 'make elaborate plans for the painting', he tells himself, 'then do it very quickly'. ${ }^{5}$

Andrews, as this note suggests, was doing more than thinking about the endless hours he was spending in front of his more ambitious pictures; he was also thinking afresh about how best he might prepare to paint such pictures. More particularly, he was thinking that summer about how he might prepare himself to paint a new, largescale picture on a subject with which he, like so many other artists, photographers, writers, and film-makers of the period, had become utterly fascinated: that is, the decadent, transgressive, and nihilistic forms of party-going and nightlife that had emerged in the cities of post-war Europe and America, and that operated in the cultural shadows of what John Kenneth Galbraith, in a classic best-seller of the late 1950s, famously described as the Affluent Society. ${ }^{6}$ The Colony Room saw Andrews addressing this topic in a local and limited way; now, however, he was keen to embark upon a painting that would, in his own words, 'writ the whole thing large', and address the phenomenon of modern parties and nightlife, and the rituals with which they were associated, on a broader, more international basis. ${ }^{7}$

To do this, Andrews decided to embark upon an intense period of planning prior to beginning his new work, in which he would immerse himself in novels, films, and news stories on the topic, both old and new. And, in an even more important step, he decided that, as part of this mode of research, he would start putting together an image-bank of relevant photographs on his studio walls, culled from newspapers, magazines, journals, and picture-books. Andrews had decorated his studio walls with photographs in the past, and, once in a while, used their motifs for his paintings.

\footnotetext{
${ }^{4}$ Transcript of interview with Andrews for BBC Omnibus programme, broadcast on 29 January 1991 (Andrews family archive).

${ }^{5}$ Michael Andrews, Diary 1962-3, entries for '9th July 62' and '12th July 62', un-paginated (Andrews family archive).

${ }^{6}$ John Kenneth Galbraith (1958).

${ }^{7}$ Transcript of interview with Andrews for BBC Omnibus programme, broadcast on 29 January 1991 (Andrews family archive).
} 


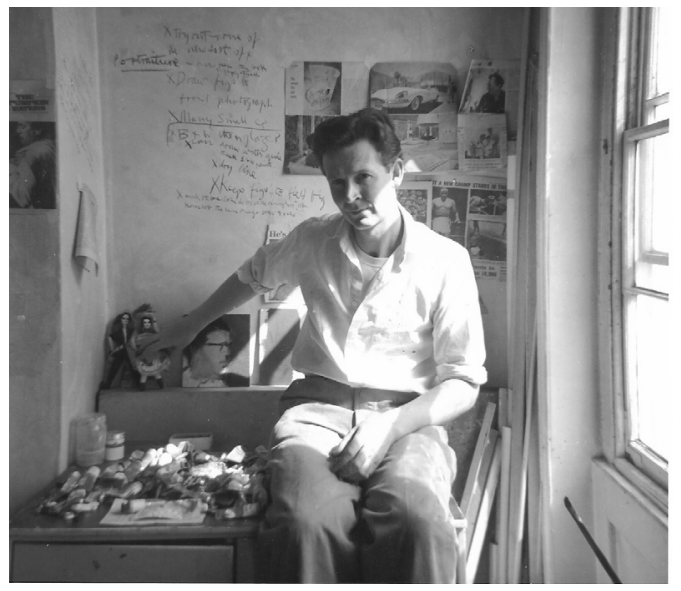

Figure 8. June Keeley (now Andrews), photograph of Michael Andrews in his Islington Studio, 1963. (C) June Andrews.

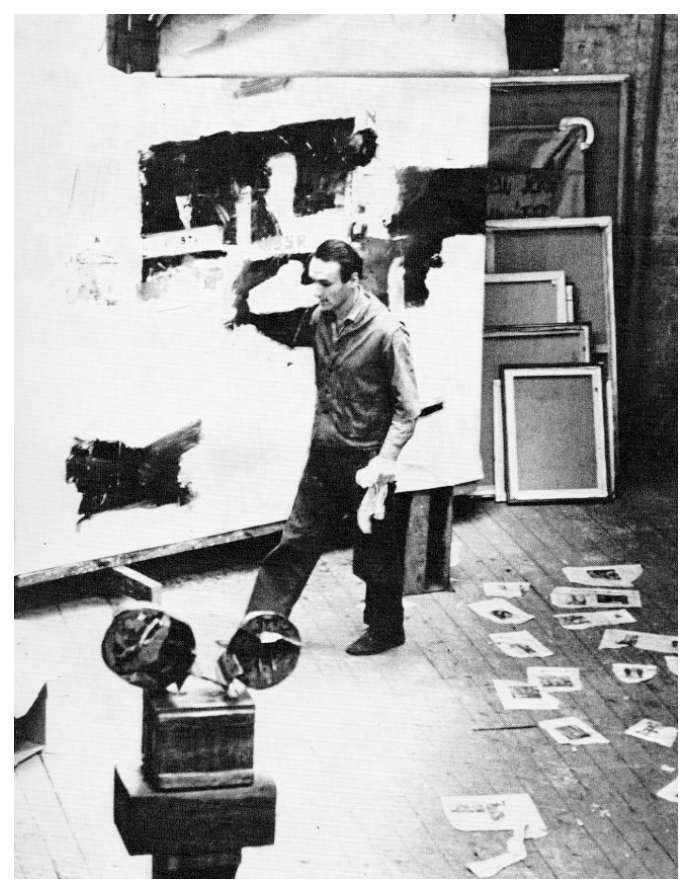

Figure 9. Anonymous, Larry Rivers in his studio, 1962. Photograph in the Larry Rivers exhibition catalogue, Gimpel Fils Gallery, London 1962 (London: Gimpel Fils Gallery, 1962). (C) The estate of Larry Rivers.
But this was different. Crucially, the photographs that Andrews was now assembling on his walls were going to provide him with all the visual sources he needed for his new painting, and they were going to be images from which he would directly quote. In this process, as is nicely suggested by a more relaxed photograph of the artist taken in the spring of 1963 (Figure 8), it was not only the studio mantelpiece that found itself being surmounted with torn-out newspaper and magazine pages; so, too, did the other walls of his workplace, across which-as this photograph also reveals-he would regularly scribble a series of notes, questions, and reminders to himself, to help him in his research and practice.

In embracing photography in this way, Andrews was pulling away from the artistic precepts he had learnt at the Slade, and aligning himself with an alternative strand of modern British and American painting. Earlier in the century, Walter Sickert had famously rifled contemporary newspapers for press-photographs, which he would then adapt in his paintings of modern celebrity and tragedy. ${ }^{8}$ Even more obviously, Andrews' great friend and mentor Francis Bacon, whose studio was similarly clogged with newsprint and photographic cut-outs, had consistently used such materials as the basis of his paintings over the previous

${ }^{8}$ For an interesting discussion of Sickert's use of photographs in his late painting practice, see David Peters Corbett (2001: 58-62). 
decade. ${ }^{9}$ This engagement with photography, and the wider newsprint culture of which it was so central a part, was also to found in the work of a number of young American painters who were enjoying prominence in Britain in the early 1960s, including Larry Rivers and Robert Rauschenberg. The portrait of Rivers that illustrated the catalogue of a 1962 London exhibition of his work makes the connection abundantly clear (Figure 9): here, the artist strides across a studio floor scattered with torn newspaper and magazine pages, each one of which is bedecked with the kind of imagery that helped furnish and stimulate his paintings. ${ }^{10}$

There was another, related aspect to Andrews' change in direction in the summer of 1962: his dramatic turn to collage. He would have been fully aware that artists like Rivers and Rauschensberg, alongside their engagement with photography and newsprint, were revelling in collage-like forms of pictorial composition, and in the juxtaposition of borrowed and seemingly disconnected images and objects, extracted from their previous visual realms and recombined to new effect: as examples of this process, we can point to Rauschenberg's Rebus ${ }^{11}$ from 1955, and a photograph of Rivers and his collaborator, the poet Kenneth Koch, in front of their poem-painting New York, New York, 1950-1960 (Figure 10). This collage mode of picture-making

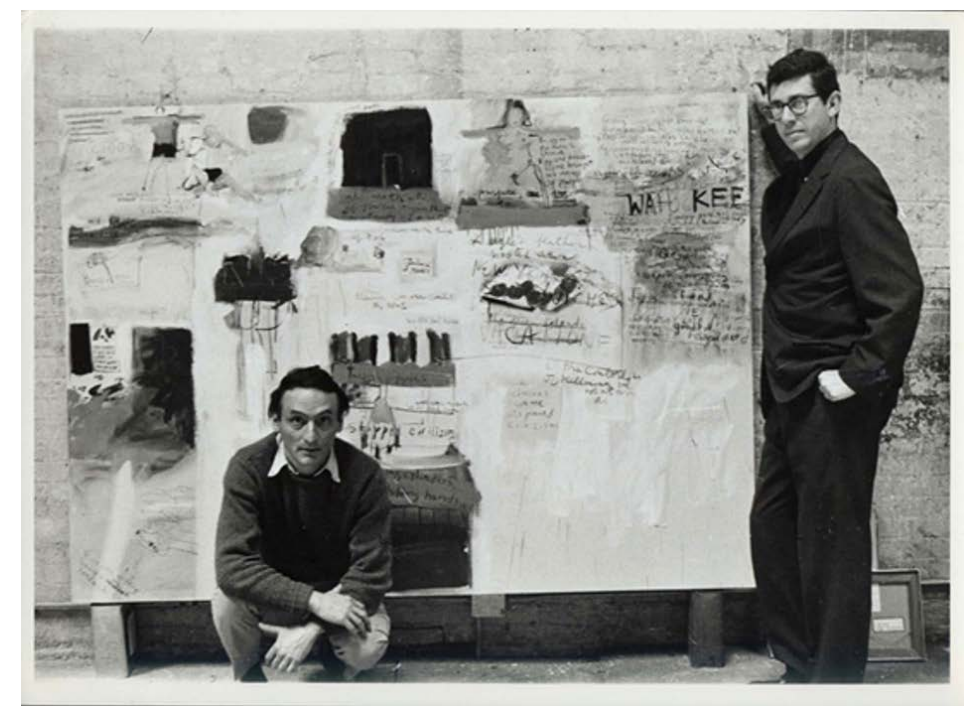

Figure 10. Anonymous, Larry Rivers and Kenneth Koch with their painting New York, New York, 19501960, photograph, 1961. (C) The estate of Larry Rivers / Kenneth Koch.

\footnotetext{
${ }^{9}$ For a concentrated study of this aspect of Bacon's practice, see Martin Harrison (2005).

${ }^{10}$ Rivers, catalogue produced by Gimpel Fils gallery, London, for exhibition in May 1962.

${ }^{11}$ Robert Rauschenberg, Rebus, 1955, oil, synthetic polymer paint, pencil, crayon, pastel, cut-and-pasted printed and painted papers, including a drawing by Cy Twombly, and fabric on canvas mounted and stapled to fabric, $244 \times 333 \mathrm{~cm} \times 4.4 \mathrm{~cm}$, The Museum of Modern Art, New York (see https://www. moma.org/collection/works/98673).
} 
was also being renewed in the practice of Andrews' British contemporaries. This was especially true of a younger generation of artists coming through the Royal College of Art schools - Peter Blake, ${ }^{12}$ David Hockney, and R. B. Kitaj amongst them-whose collage-like paintings and assemblages were being assiduously promoted as the most innovative form of British contemporary art, particularly on the part of new media outlets such as the Sunday Times Colour Section, the first issue of which, in February 1962, featured an article on Blake. ${ }^{13}$

This interest in painted collage on the part of both British and American artists must have been one factor in encouraging Andrews himself, in the summer and autumn of 1962, to consider experimenting with a similar kind of method. He must also have envisaged that this mode of working would prove especially well-suited to the kind of subject - the discordant and fragmented dynamics of contemporary nightlife - that he wished to address in the new, multi-figural, picture that was taking shape in his imagination over the summer and autumn of 1962 . Whatever the precise mix of his motivations and stimuli, he decided to give it a go. At the end of that same year, having done all the 'elaborate planning' he could, and wishing to spring a surprise at his forthcoming Lessore Gallery exhibition - which had now been postponed to January 1963 - he set about trying to manufacture a new kind of collage-like picture, painted in the 'cursive and running style' of which he had been dreaming for so many months.

\section{III}

The Deer Park (Figure 11), painted over the last six weeks or so of 1962, in what for Andrews was breakneck speed, was the result. The picture is a hectic and confusing one, and deliberately so. It is structured by the roller-coaster sweep and plunge of a balcony and stairwell down to its left, and by the odd combination of semi-transparent screen and curved viewing platform on its right. This strange, almost free-floating, architecture pours forth a crowd of men and women who variously dance, embrace, sit, and talk, and who spill out into the lush green landscape in the background. The painting's sense of flux and uncertainty is reinforced by its sketch-like and visibly rushed character; it really does have the feel of a picture painted in a hurry.

\footnotetext{
${ }^{12}$ A good example is Peter Blake's Girls with their Hero, 1959, acrylic on board, $134 \times 125 \mathrm{~cm}$. Pallant House Gallery, Chichester, gift from Colin St John Wilson through the National Art Collections Fund, 2004 (see https://artuk.org/discover/artworks/girls-with-their-hero-70704).

${ }^{13}$ The first issue of The Sunday Times Colour Section was published with the newspaper on 4 February 1962. This carried an article on Blake by John Russell entitled 'Pioneer of Pop Art (People of the 60s)'.
} 


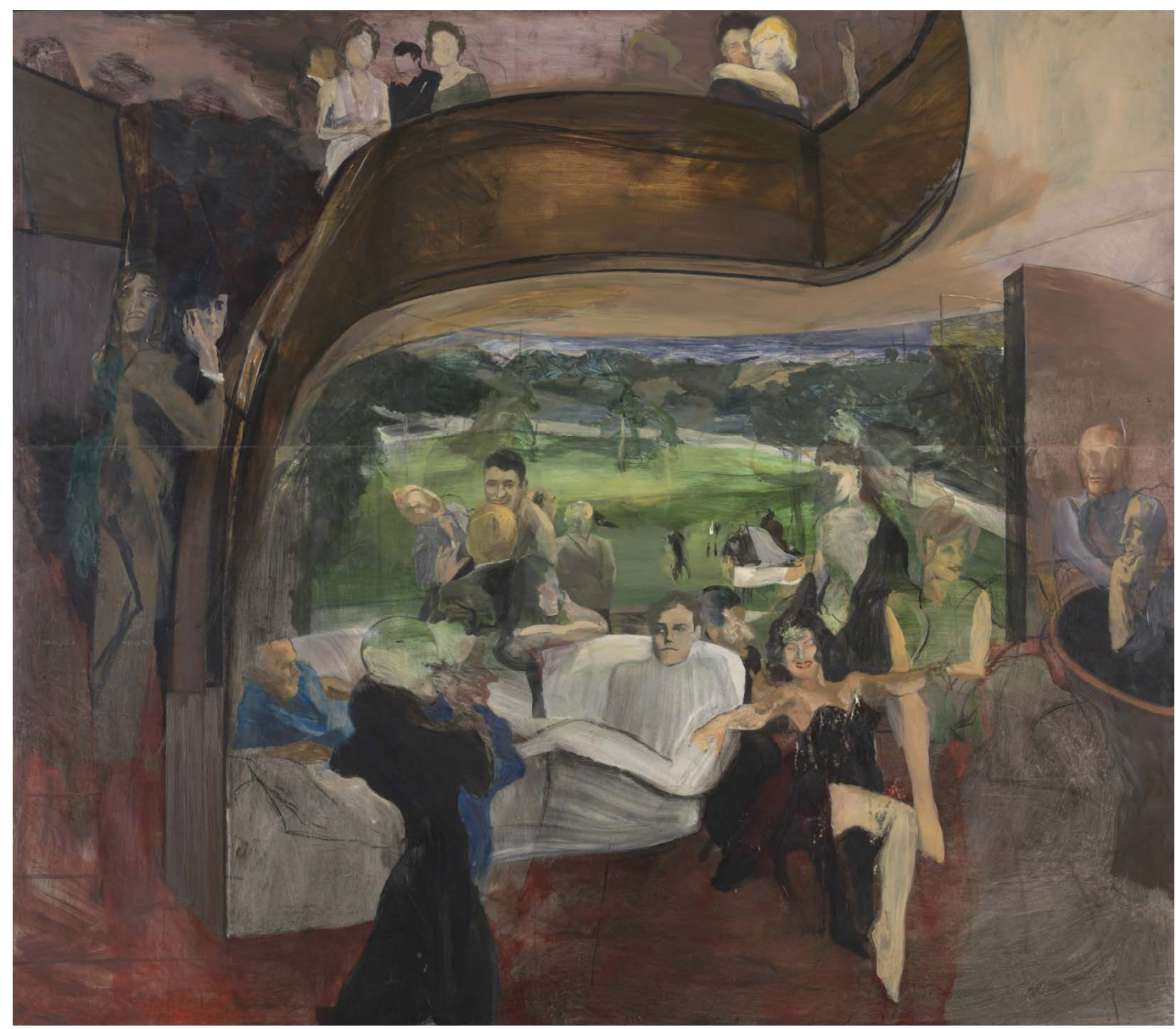

Figure 11. Michael Andrews, The Deer Park, 1962, oil on board, $214 \times 245 \mathrm{~cm}$. (C) The Estate of Michael Andrews / Tate.

As all previous writers on the painting have observed, this busy image owes its title and many of its central concerns to Norman Mailer's 1955 novel Deer Park, of which Andrews was a great admirer. ${ }^{14}$ Telling an ultimately melancholy story of America's glamorous but shallow film culture, Mailer's novel is set in the fictional, newly constructed town of Desert D'Or, a thinly disguised version of Palm Springs in California, and is built upon the encounters between its young yet world-weary narrator and the temporarily displaced denizens of Hollywood-controversial directors, troubled starlets, exploitative producers, secretly gay leading men, prostitutes, photographers, and nightclub dancers. The book's plot is punctuated by a succession of parties and drinking-sessions, sometimes going on for days on end: 'a week went by of watered

${ }^{14}$ Norman Mailer, The Deer Park (1955, first UK edition 1957). 
whisky, dim rooms, and the curving walls of Desert D'Or architecture' ${ }^{15}$ Relationships and conversations evolve and curdle, but in Desert D'Or's background there is always the same sound: 'below them, partially muted, they could hear the eager, avaricious noise of the party'. ${ }^{16}$

Mailer's narrator wanders through this hazy, drink-soaked realm as a fascinated but detached observer. Andrews' painting, which powerfully evokes the kinds of setting and socialising described in the novel, not only places us, as spectators, at a similar remove, but incorporates the figures of two internal male observers, their heads resting in their hands, who look out at the party from its margins. One of these figures, on the far right, provides us with a first, telling instance of Andrews' pictorial borrowing in The Deer Park: it is a portrait of the author Ian Fleming, taken from the dust-jacket of his 1956 James Bond novel Diamonds Are Forever (Figure 12). Significantly, Fleming's book sees Bond drinking, gambling, and womanising in

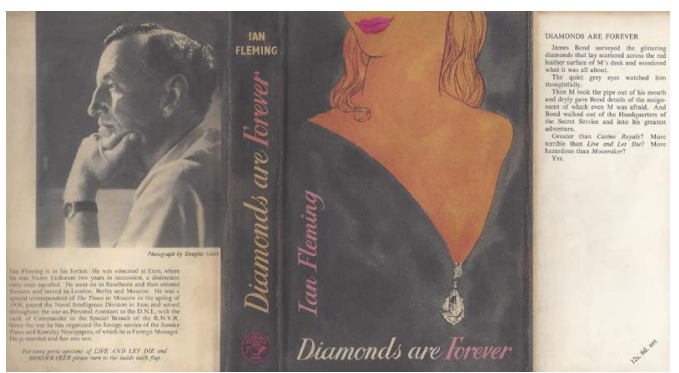

Figure 12. Diamonds are Forever book jacket featuring photograph of Ian Fleming by Douglas Glass, 1956 (C) The estate of Douglas Glass.

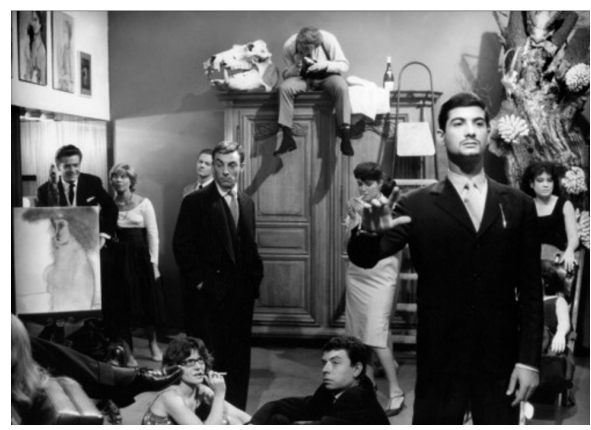

Figure 13. Film still from Les Cousins by Claude Chabrol (director), 1959. (C) Ajym Films, Société Française du Cinéma pour la Jeunesse. another modern pleasure-ground newly erected in the American desert - this time, Las Vegas - in pursuit of a gang of mobsters and diamond-smugglers. The author's presence in Andrews' painting opens up and complicates its literary allusions, inviting us to imaginatively map the pictured scene not only onto Mailer's book, but onto the similarly modern, superficially glamorous, and cocktailfuelled world of the Bond novels.

The parallels and dissonances generated by this form of pictorial grafting only multiply as we start delving into other parts of the painting, and into the other works that shaped its contents. In a diary entry of 7 August 1962, already headed with the title Deer Park, the artist listed a series of other points of reference: one was to the 'décor' of Claude Chabrol's 1959 film, Les Cousins. ${ }^{17}$ Chabrol's film, which follows a naïve young countryman as

\footnotetext{
${ }^{15}$ Mailer (1962: 217).

${ }^{16}$ Mailer (1962: 227).

${ }^{17}$ Michael Andrews, Diary 1962-3, entry for '7th Aug', un-paginated (Andrews family archive).
} 
he becomes increasingly entangled in a decadent and extravagant metropolis, centres upon a debauched and ultimately violent party held in a split-level Paris apartment (Figure 13). ${ }^{18}$ In talking to critics on Deer Park's completion, Andrews was happy to flag the ways in which his new painting related to such films; thus, David Sylvester, having interviewed the artist, wrote that the interior of Deer Park was 'inspired mainly by the apartment in the film Les Cousins, and also by the houses where parties were held in [Michelangelo Antonioni's] La Notte and L'Avventura and [Federico Fellini's] La Dolce Vita'.$^{19}$ Yet Andrews' engagement with such films went far beyond a concern with their décor, and was just as crucially focused upon their narratives of hedonistic pleasure, social excess, and individual alienation. Especially important to him in this respect was Antonioni's La Notte (Figure 14), ${ }^{20}$ the final part of which centres upon

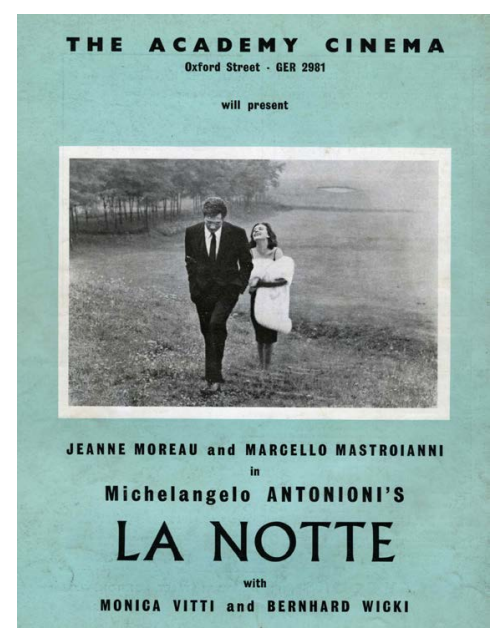

Figure 14. Advertisement for La Notte by Michelangelo Antonioni's, back cover of Sight and Sound, winter issue, 1961-2 (London: BFI, 19612). (C) BFI. an extravagant party, and which ends with the film's two protagonists, played by Marcello Mastroianni and Jeanne Moreau, leaving the modernist building in which the party is held, walking past a piano-player playing music on the lawn, and wandering out into an empty, expansive, landscape. Tracking into the background of Deer Park, we see that Andrews takes our eye on precisely the same kind of journey, through the fringes of his own party, past another piano - this time a white oneand out into a wide-open, emptied green space that is similarly flecked with the dark, isolated silhouettes of drifting party-goers.

Films, novels, and book-jackets were joined by paintings and news-photographs in the mulch of materials that went into the making of Deer Park. Letters written by Helen Lessore to Andrews in late August 1962 make it clear that he had not only recommended Les Cousins to her, but told her about the importance of Diego Velazquez's Philip IV Hunting Wild Boar (Figure 15) to his new venture. ${ }^{21}$ Velazquez's work, which was painted for Philip IV in the 1630s, and which serves as the primary pictorial basis

\footnotetext{
${ }^{18} \mathrm{See}$ https://www.youtube.com/watch?v=4mauh8gcm0U $(0.00-0.27)$.

${ }^{19}$ David Sylvester (1963: 15).

${ }^{20}$ See https://www.youtube.com/watch?v=o9vDQFkHwJo (1:31:01-1:41:55).

${ }^{21}$ See letter from Helen Lessore to Michael Andrews, dated 'August 27' [1962] (Tate Gallery Michael Andrews archive, TGA 200025/1/1/5/3).
} 


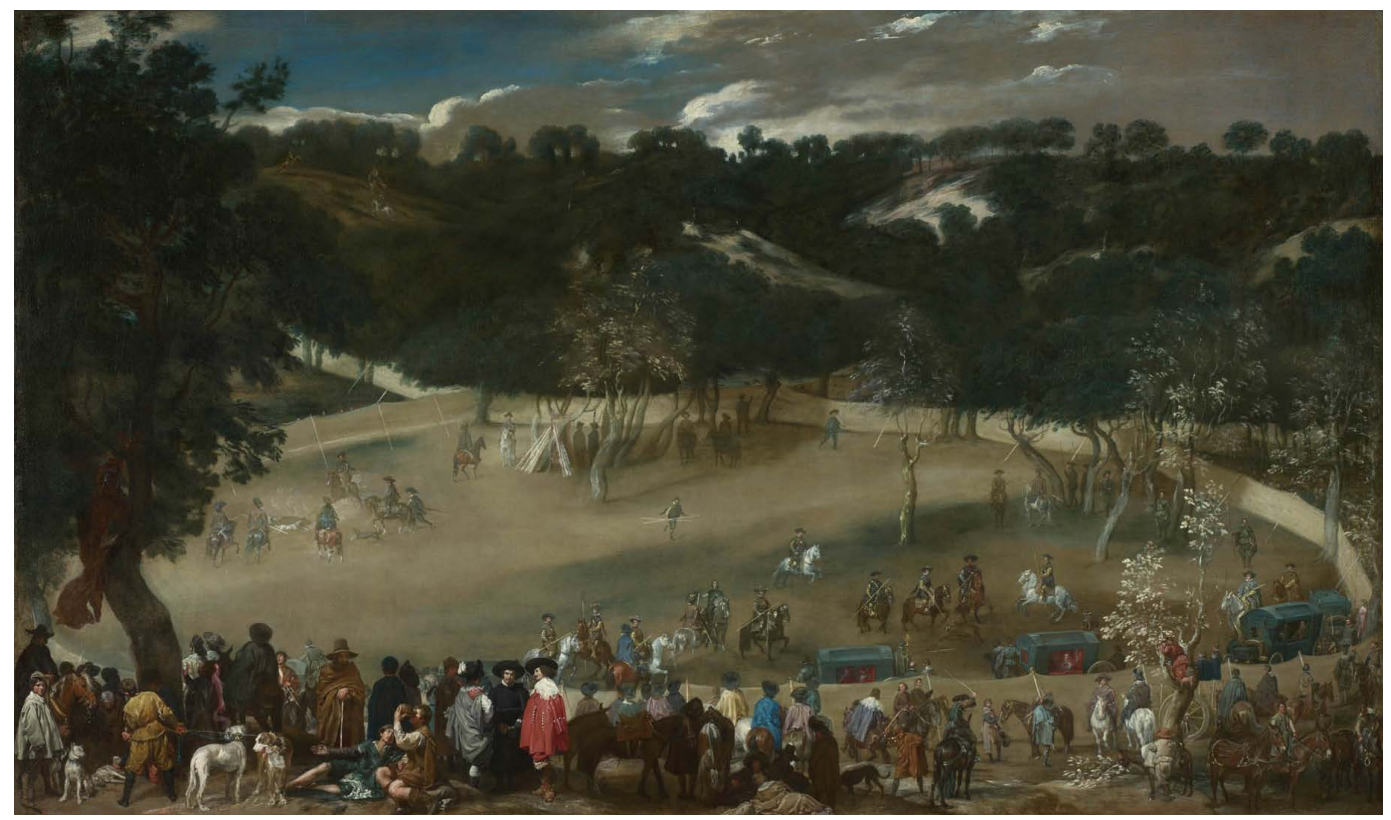

Figure 15. Diego Velazquez, Philip IV hunting Wild Boar, c. $1632-7$, oil on canvas, $182 \times 302 \mathrm{~cm}$. C The National Gallery, London.

for Deer Park's background landscape, focuses on one of the most flamboyant rituals of the Spanish king's court. This was a boar-hunting tournament that took place in a cordoned-off enclosure, here shown surrounded by a crowd of lackeys and servants, whiling away the time while their betters are at play. The reference to Velazquez's image of an early-modern courtly pleasure ground chimes with one of the epigraphs to Mailer's Deer Park, which Andrews also mentioned to Lessore in the same month. ${ }^{22}$ The epigraph quotes from Mouffle D'Angerville's scandalous 18th-century memoir of the court of Louis XV in France, which laments the corrupting influence of a royal brothel-nicknamed the Deer Park - in which the notoriously lazy and lecherous king would consort with pimps and prostitutes. ${ }^{23}$ Mailer saw the same courtly patterns re-establishing themselves in his modern Deer Park. 'In the off-season', he writes, 'any celebrity who lived in Desert D'or was surrounded by a court. It did not matter where you went to visit; dependably there would be the same people pouring the host's

\footnotetext{
${ }^{22}$ See letter from Helen Lessore to Michael Andrews, dated 'Aug 23rd 1962' (Tate Gallery Michael Andrews archive, TGA 200025/1/1/5/38).

${ }^{23}$ The epigraph begins: ' $\ldots$ the Deer Park, that gorge of innocence and virtue in which were engulfed so many victims who when they returned to society brought with them depravity, debauchery and all the vices they naturally acquired from the infamous officials of such a place'. D'Angerville's Vie Privée de Louis $X V$ was first published in London in four volumes in 1781.
} 
drinks, laughing at his remarks, working I suppose as servants of his pleasure, so that his favourite games were played, his favourite stories were told, and the court was split into cliques which jockeyed for his favour. ${ }^{24}$ Andrews' painting, in juxtaposing Velazquez's landscape with a scene so redolent of the sexual intrigue and social manoeuvring highlighted in both D'Angerville and Mailer's texts, gestures to the continuities between decadent courtly cultures both old and new.

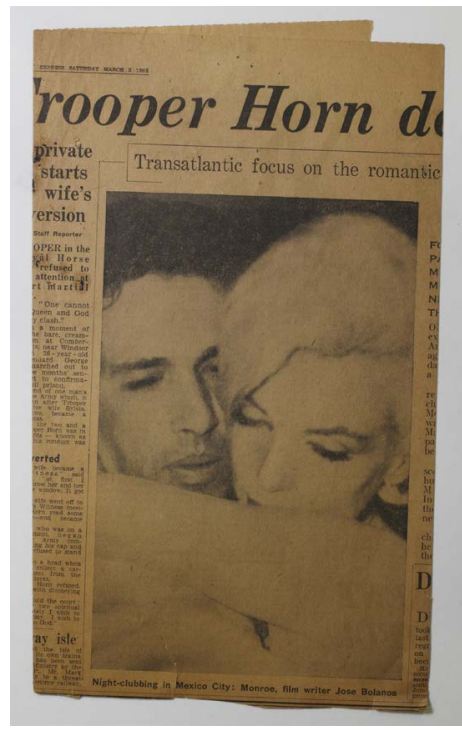

Figure 16. Newspaper clipping from Daily Express, March 1962. (C) Tate archive.

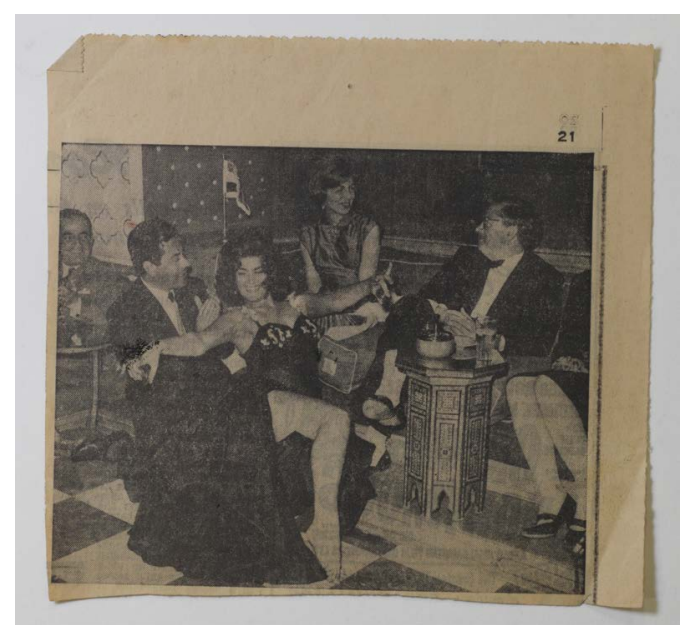

Figure 18. Unidentified newspaper clipping, c. 1962. (C) Tate archive.

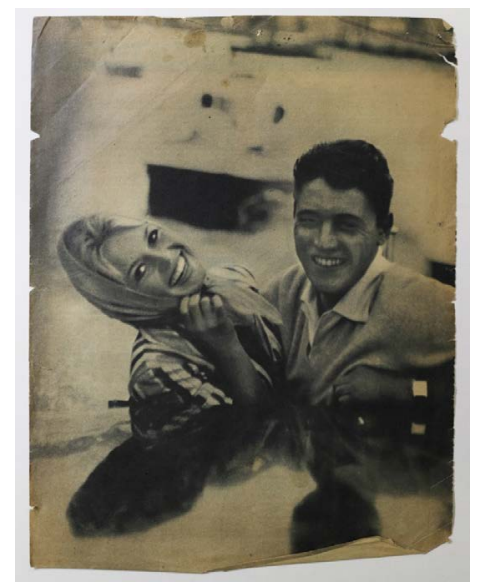

Figure 17. Unidentified magazine photograph of Brigitte Bardot and Sacha Distel at the Venice Film Festival, 1958. (C) Tate archive.

As well as appropriating Old Master painting, Andrews raided contemporary newspapers and magazines for images of the stars whose surrogates dot Mailer's narrative, and for pictures that might evoke the novel's parallel array of pleasure-seekers and idling rich. A Daily Express photograph of Marilyn Monroe dancing with the Mexican scriptwriter Jose Bolano (Figure 16), from the spring of 1962, provided the basis for the detail of the embracing couple on the upper balcony. ${ }^{25} \mathrm{~A}$ magazine photograph of Brigitte Bardot and Sacha Distel taken at the 1958 Venice Film Festival (Figure 17)

${ }^{24}$ Mailer, (1962: 13).

${ }^{25}$ Tate Michael Andrews Archive TGA 200025 $3 / 2 / 1$. 


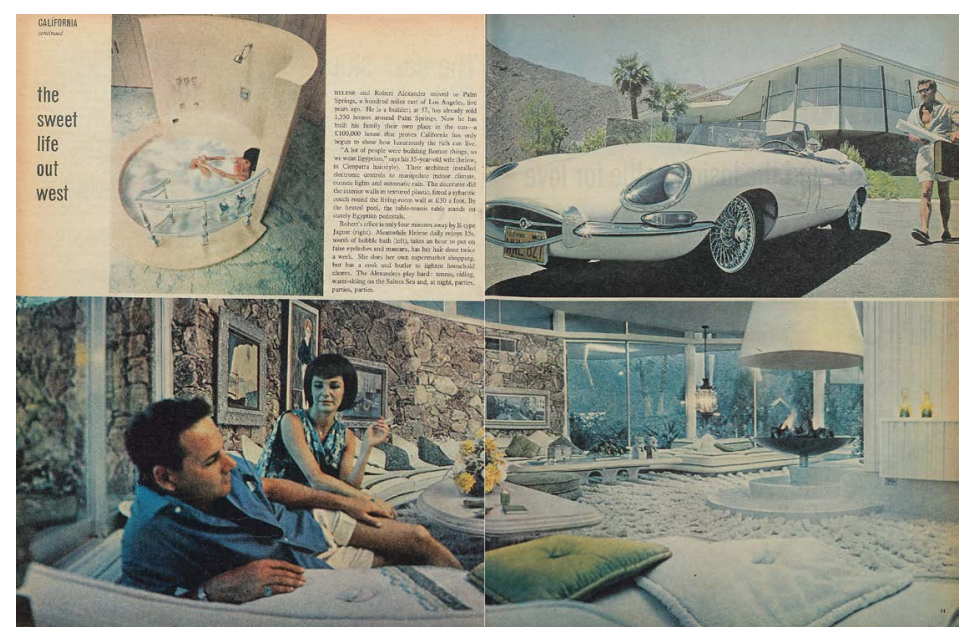

Figure 19. 'the sweet life out west', double-page spread in The Sunday Times Colour Section, December 16, 1962. (C) Times Newspapers Ltd.

is transformed into the couple who laugh in the painting's mid-ground. ${ }^{26}$ And a newspaper photograph taken in an exotically themed night club (Figure 18), featuring a smiling dancer with her arms outstretched and her leg exposed, is used as the basis for a trio of figures found in Deer Park's foreground. ${ }^{27}$

Perhaps the most telling of such quotations, however, is that taken from an issue of The Sunday Times Colour Section published on 16 December 1962-that is, right in the middle of the period when Andrews was rushing through his painting. The magazine was headlined with the words 'California: The Tarnished Paradise', and featured a double-page spread enjoying the title 'the sweet life out west' (Figure 19). ${ }^{28}$ This offered a picture story of the property developer Robert Alexander and his wife Helene, and their life of luxury in Palm Springs. The accompanying commentary sets the tone: " "A lot of people were building Roman things, so we went Egyptian," says [Robert's] 35-year-old wife (below, in Cleopatra hairstyle).' The caption goes on: 'Their architect installed electronic controls to manipulate indoor climate, outside lights and automatic rain. The decorator did the interior walls in textured plastic, [and] fitted a sybaritic couch round the living-room wall at $£ 30$ a foot.' The caption ends with the ringing punchline: 'The Alexanders play hard: tennis, riding, waterskiing on the Salton Sea and, at night, parties, parties, parties. ${ }^{29}$ How Andrews must have loved that final sentence! He proceeded to cut out this double-page spread and,

\footnotetext{
${ }^{26} \mathrm{Ibid}$.

${ }^{27}$ Ibid.

${ }^{28}$ Sunday Times Colour Section (16 December 1962, pp. 10-11).

${ }^{29}$ Ibid.
} 


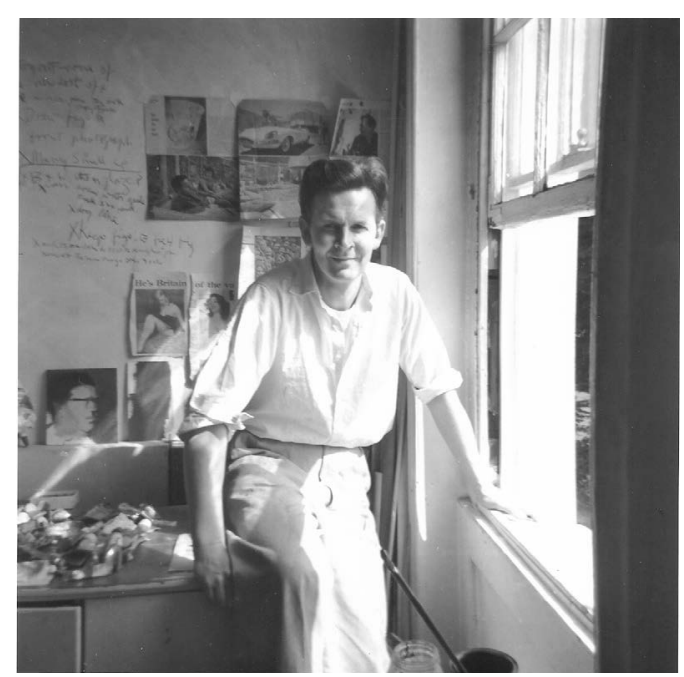

Figure 20. June Keeley (now Andrews), photograph of Michael Andrews in his Islington Studio, 1963. (C) June Andrews.

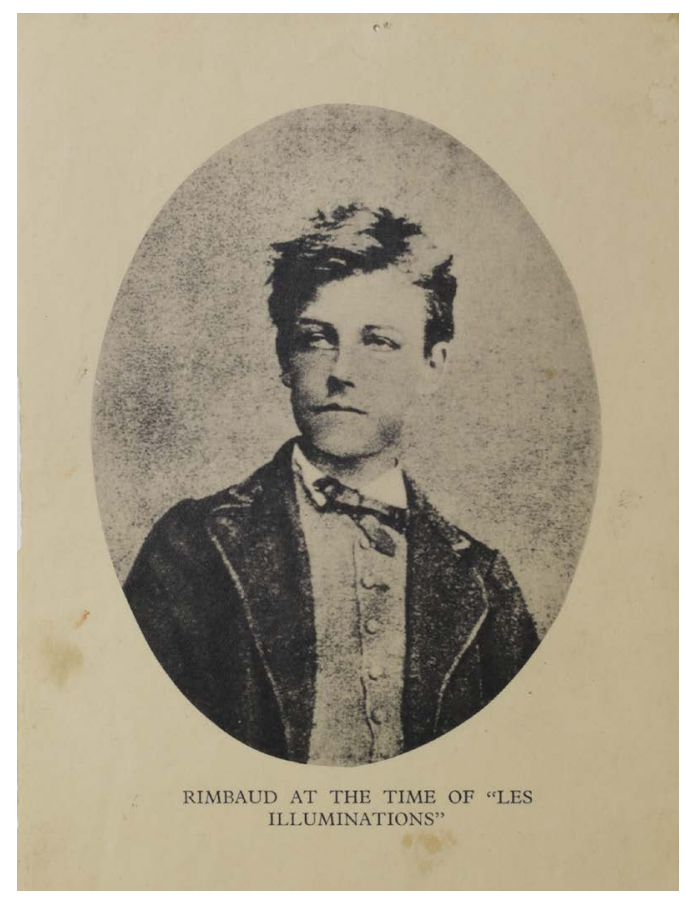

Figure 21. "Rimbaud at the time of "Les Illuminations", in Enid Starkie, Arthur Rimbaud, London, 1947 (London: Hamish Hamilton, Penguin Random House, 1947). (C) Hamish Hamilton, Penguin Random House. as can be seen if we return to a companion of the sunny snapshot noted earlier, to pin it up on the wall next to his studio window (Figure 20). He then went on to introduce Robert Alexander's pictorial double into Deer Park, where we find him at the bottom of the stairwell, lounging on another sybaritic couch.

Intriguingly, he shares that couch with a figure who is little more than a thinly painted head placed on some outlined shoulders, and whom Andrews intended as a portrait of the most mysterious and chilling protagonist in Mailer's novel, the reclusive pimp Marion O'Faye. In the painting of Deer Park, O'Faye's strange face, which seems to glower out at the assembly with contempt, is based on a late-19th-century photograph of the French poet Arthur Rimbaud (Figure 21). It has become the stuff of literary folklore that Rimbaud's visionary and dream-like poems were written when he was astonishingly young, and that he lived a life of remarkable freedom and rebelliousness. Andrews, like many other painters and writers of the beat era, seems to have valorised the poet as the quintessential bohemian and outsider. As has just been noted, he was not alone-here is the American poet Allen Ginsberg in Paris in 1956 (Figure 22), sitting directly in front of an image of Rimbaud taken from Henri FantinLatour's 1872 group portrait of avant-garde French poets (Figure 23). Nevertheless, Andrews seems to have identified with Rimbaud to a rather 


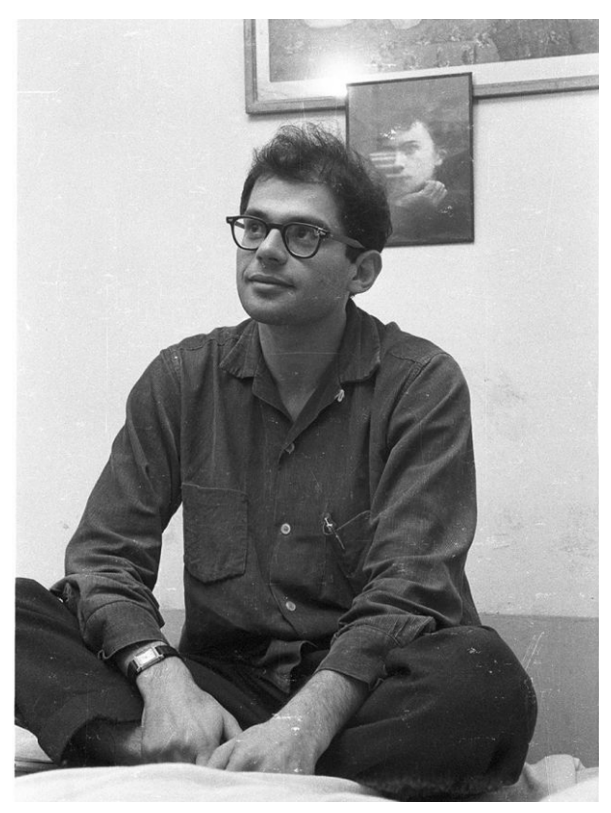

Figure 22. Harold Chapman, photograph of Allen Ginsberg in Paris, December 1956. (C) Harold Chapman / TopFoto. extraordinary degree, something that can be better gauged if we return to that John Deakin portrait we looked at earlier (see Figure 5). There, we find not only the pinned-up photograph of Rimbaud upon which O'Faye's portrait in Deer Park is based, but two related photographs, both of which, like that of their companion, come from the 1947 edition of Enid Starkie's biography of the poet. ${ }^{30}$ One (Figure 24) is another image of Rimbaud himself, taken in later life, and the other (Figure 25) is of his sister, Vitalie. Not only that, but the postcard that hovers over Andrews' left shoulder reproduces that same group portrait by Fantin-Latour.

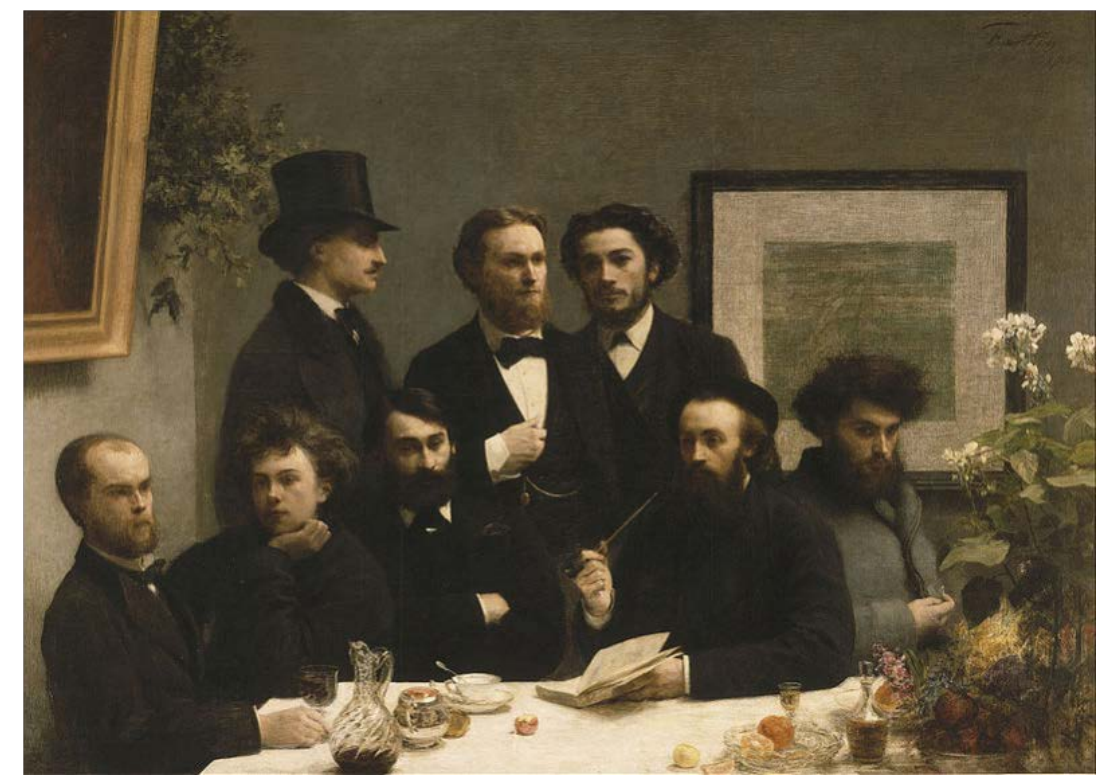

Figure 23. Henri Fantin-Latour, Corner of a Table, 1872, oil on canvas, $160 \times 225 \mathrm{~cm}$. C Musée d'Orsay, Paris.

\footnotetext{
${ }^{30}$ Enid Starkie, Arthur Rimbaud (Hamish Hamilton,1947).
} 


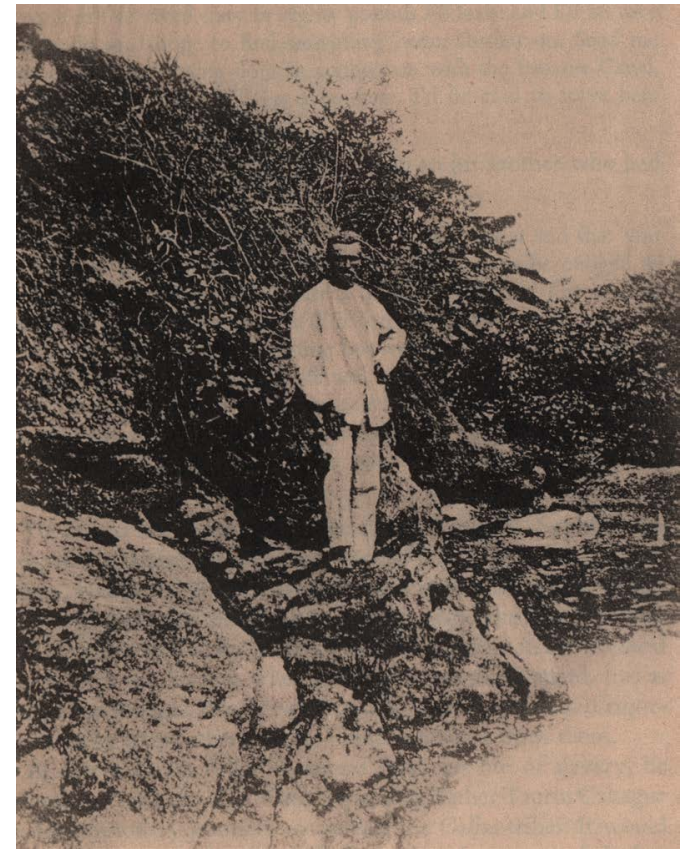

Figure 24. 'Rimbaud at Harar in 1883', in Enid Starkie, Arthur Rimbaud, London, 1947 (London: Hamish Hamilton, Penguin Random House, 1947). (C) Hamish Hamilton, Penguin Random House.

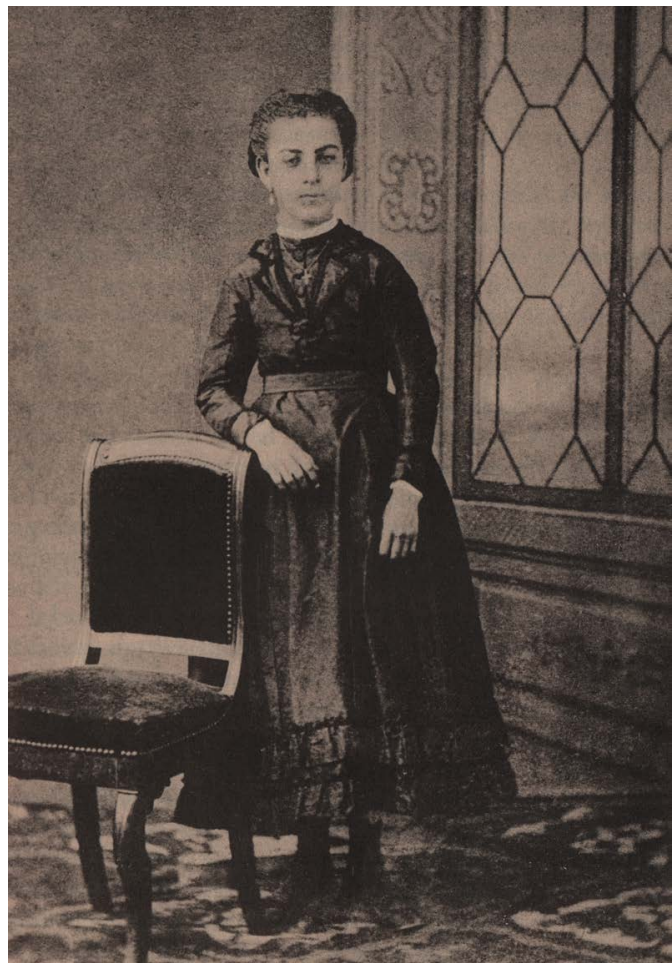

Figure 25. 'Vitalie Rimbaud', in Enid Starkie, Arthur Rimbaud, London, 1947 (London: Hamish Hamilton, Penguin Random House, 1947). (C) Hamish Hamilton, Penguin Random House.

Andrews, who remembered reading 'a lot' of Rimbaud during the time he was painting Deer Park, explained his choice of pictorial model by noting that 'Marion O'Faye must have had a deadly kind of charm and was guided by fate and Rimbaud was a parallel figure. ${ }^{31}$ But, as Ben Tufnell has noted, the introduction of the poet's portrait into Deer Park also proclaims Andrews' own adherence to the ideal of artistic freedom for which Rimbaud served as such a talisman..$^{32}$ More particularly, Rimbaud's presence at the centre of the painting seems to symbolise and express the forms of artistic freedom, even of liberation, that Andrews himself experienced when painting this work, which he later wrote was 'one of the pictures which has given me the greatest excitement painting. I went directly for excitement. ${ }^{93}$ This excitement, we can conclude,

${ }^{31}$ Quoted in Simon Wilson's Tate catalogue entry on the painting, first published in The Tate Gallery 1974-6: Illustrated Catalogue of Acquisitions, London, 1978; accessed online at https://www.tate.org.uk/ art/artworks/andrews-the-deer-park-t01897, April 2019.

${ }^{32}$ See Ben Tufnell (2001: 91).

${ }^{33}$ Quoted in Wilson catalogue entry, op. cit. 
lay not only in the energy and speed he brought to the picture, but also in the novelty of undertaking an entirely new way of generating an image, in which a mass of visual materials, all very different from each other, but all dealing with the same kinds of subject, are put into thrilling, cacophonous dialogue.

\section{IV}

'One of the most ambitious and original of recent English pictures'; 'An extraordinary bundle of contradictions and ambiguities'; a painting 'of huge ambition': the reviews attracted by Deer Park at the 1963 Lessore Gallery show must have helped convince Andrews that he should press on with a successor. ${ }^{34}$ In any case, he had already been thinking of a sequence of such pictures as early as the previous August, when his diary reveals him imagining 'A series called the Deer Park'; accordingly, he followed up the Lessore show by beginning a new painting in a similar vein, to which he gave the working title Deer Park $2 .{ }^{35}$ He later recalled the way in which he had approached this pictorial sequel: 'after I'd done The Deer Park, I wanted to paint a more level-headed version of it because it went very fast and there were areas of it which I felt could be amplified, painted better'. ${ }^{36}$ This new picture (Figure 26), to

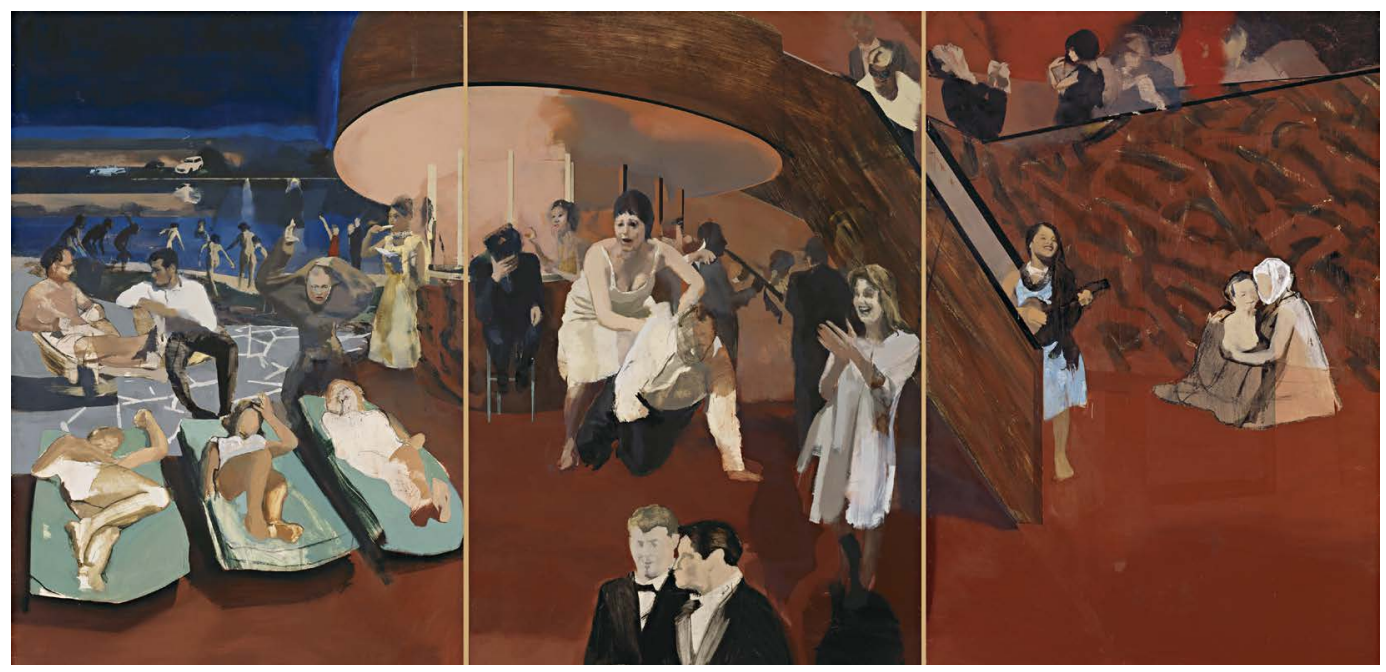

Figure 26. Michael Andrews, All Night Long, 1963-4, oil on board, in three parts, $184 \times 368 \mathrm{~cm}$ (overall). (C) The estate of Michael Andrews / The National Gallery of Victoria, Melbourne, Felton Bequest, 1964.

${ }^{34}$ John Russell, Sunday Times, 13 January 1963; anon, The Times, 16 January 1963; Edward Lucie-Smith, Listener, 24 January 1963.

${ }^{35}$ Michael Andrews, Diary 1962-3, entries for '14th Aug' and 'Nov 63', un-paginated (Andrews family archive).

${ }^{36}$ Transcript of interview with Andrews for BBC Omnibus programme, broadcast on 29 January 1991 (Andrews family archive). 
which he eventually gave the title All Night Long, once again offers a panorama of contemporary nightlife, this time divided into three sections. Andrews described All Night Long, in the same interview, as a 'serial painting' consisting of 'three $6 \times 4$ panels', and depicting, in his words, 'stages throughout the night'. ${ }^{37}$ On closer inspection, we can see that it does indeed take us on a journey across time as well as across its sprawling nightclub architecture: from the late afternoon, when a trio of sunbathers still stretch themselves out on their poolside loungers, through to the climax of a glamorous party that, with its stumbling central figures, seems on the brink of falling apart, and then on to the early hours of the morning, when the club has emptied, and a few straggling revellers dance the night away, or else wearily embrace in a quiet corner.

Andrews' ambitious intentions for his new work is suggested, in part, by its tripartite format, which so obviously duplicated the structure of Francis Bacon's great crucifixion triptychs, the most recent of which-Three Studies for a Crucifixion ${ }^{38}$ - had been produced for the artist's 1962 Tate retrospective. ${ }^{39}$ Even the similar colour schemes deployed by Andrews in All Night Long betrays, I think, the extent to which, in this new painting, he aspired to the kinds of artistic and art-historical authority being assigned to the works of his great friend. But other aspects of Andrews' painting also suggest a heightened sense of seriousness on his part, and a concerted attempt to place his picture's contemporary subject-matter into a longer, more historically grounded perspective. One example is the striking pictorial gesture he makes to Bertolt Brecht and Kurt Weill's acidly satiric Weimar opera, The Rise and Fall of the City of Mahagonny. ${ }^{40}$

Brecht and Weill's work, which had first been staged in Germany in 1930, was newly presented in London in January 1963, in a controversial Sadler's Wells production that one critic described as 'the talk of the town'. ${ }^{41}$ Andrews attended this production; and, having just finished Deer Park, he must have thought it was made for him. ${ }^{42}$ The opera is again set in a new pleasure-city built in the American desert, and attacks the corrupted underbelly of a rampantly decadent consumer culture. At Sadler's Wells, the opera's lively medley of musical forms was complemented by a very collage-like form of visual spectacle, which included the projection of various news-photographs onto the stage backcloth (Figure 27). Meanwhile, the opera's

${ }^{37}$ Ibid.

${ }^{38}$ Francis Bacon, Three Studies for a Crucifixion, 1962, oil on canvas, each $198 \times 145 \mathrm{~cm}$. (C) The Estate of Francis Bacon. All rights reserved /ARS, New York/DACS, London (see https://www.guggenheim.org/ artwork/293).

${ }^{39}$ Francis Bacon, Tate Gallery, 24 May-1 July 1962.

${ }^{40}$ For a recent, in-depth analysis of this work, see Steve Giles (editor and translator), Bertolt Brecht, Rise and Fall of the City of Mahagonny (2007).

${ }^{41}$ Edmund Tracey, Musical Times, March 1963, p. 192.

${ }^{42}$ Andrews' attendance was confirmed in a conversation with his widow, June Andrews, on 7 May 2019. 


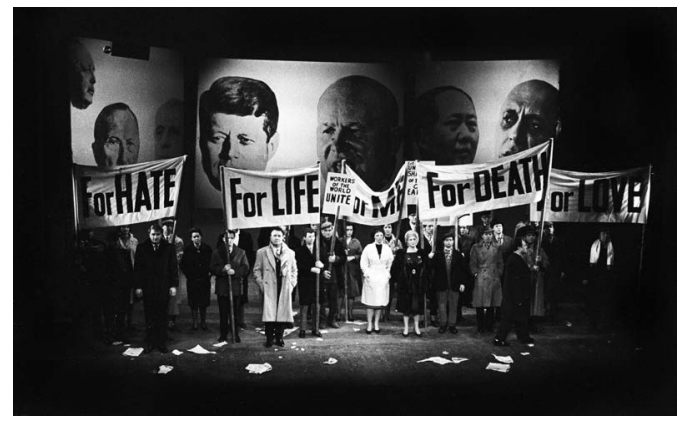

Figure 27. Alexander Low, photograph of the performance of The Rise and Fall of The City of Mahagonny, Sadler's Wells Theatre, London, 1963. (C) Alex Low / Report IFL Archive/reportdigital. co.uk

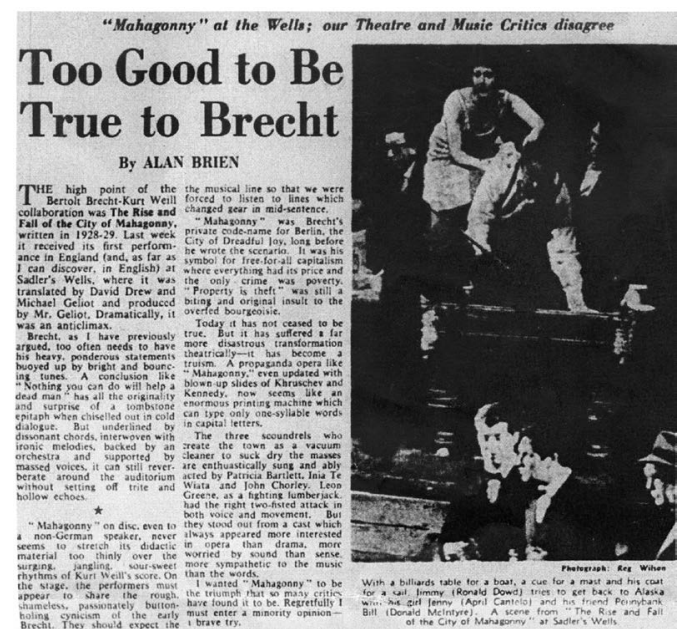

Figure 29. Newspaper clipping from The Sunday Telegraph, 20 January 1963. (C) Telegraph Media Group Ltd.

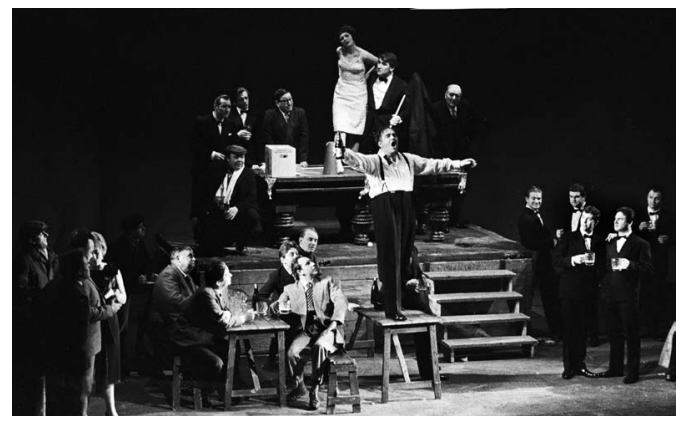

Figure 28. Alexander Low, photograph of the performance of The Rise and Fall of The City of Mahagonny, Sadler's Wells Theatre, London, 1963. (C) Alex Low / Report IFL Archive/reportdigital. co.uk

succession of set-pieces included a scene in which a mass of drinkers and dinner-jacketed party-guests observe the inebriated figure of Jimmy, and his companion, Jenny, clambering on and off a billiard table that, deluded, they imagine is a boat taking them to Alaska (Figure 28). It was a moment from this darkly farcical episode, in which Jimmy flays around on the billiard table and Jenny clutches the back of his shirt, that was captured by a press photographer and reproduced, as we have already seen, in The Sunday Telegraph on 20 January 1963 (Figure 29). And, of course, it was the figures from this image that Andrews placed at the heart of All Night Long, where we also find the painted doubles of the two dinner-jacketed men who dominate the photograph's foreground.

It seems from his diary that Andrews temporarily contemplated calling his new painting Mahagonny; if this had remained the case, the picture's references to Brecht's play would have been made thoroughly explicit. ${ }^{43}$ Instead, these references are taken underground, and become part of the mass of interlinked but partially buried associations

${ }^{43}$ Michael Andrews, Diary 1962-3, see entry for '8th March 63', in which he couples 'Mahagonny and D.Park' in what seems to be a list of current and recent pictures (Andrews family archive). 


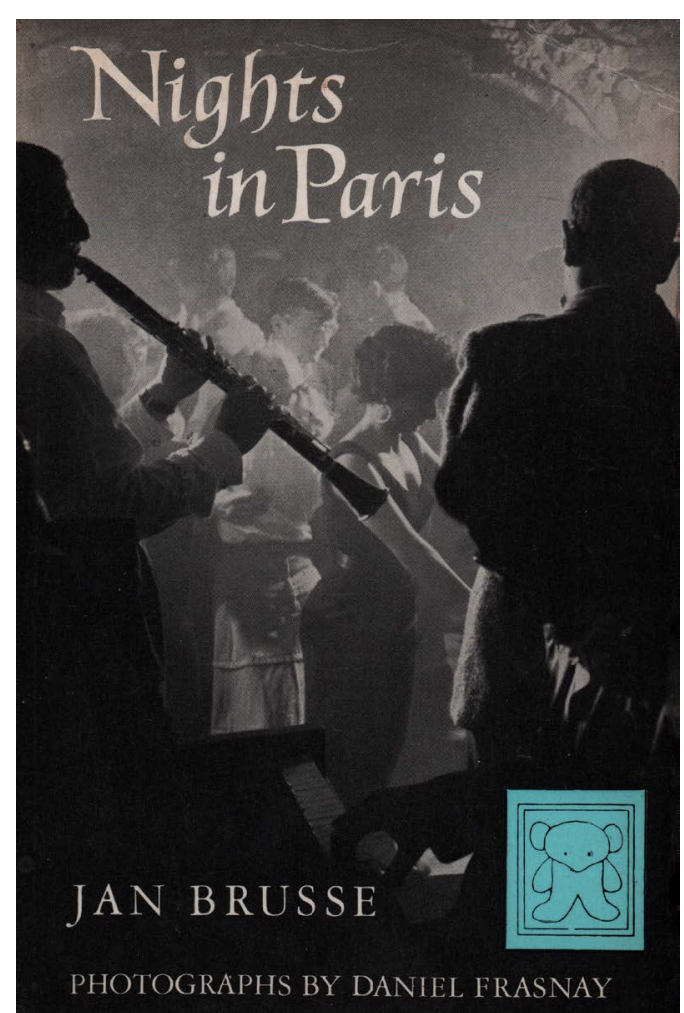

Figure 30. Daniel Frasnay, Cover of Jan Brusse, Nights in Paris, London, 1958 (London: Andre Deutsch, 1958). (C Daniel Frasnay.

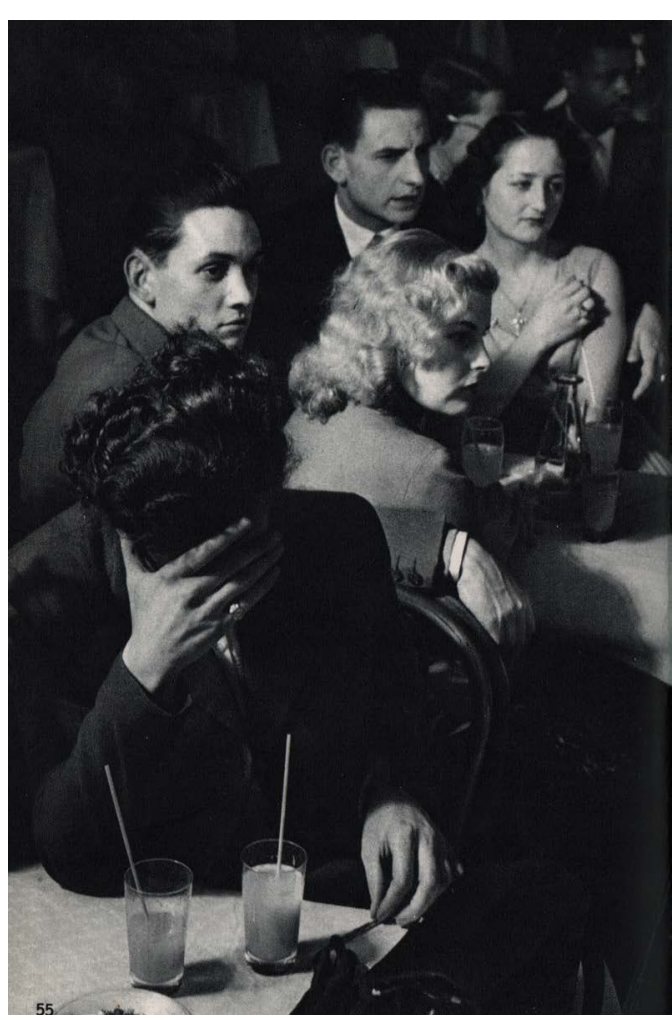

Figure 31. Daniel Frasnay, photograph in Jan Brusse, Nights in Paris, 1958 (London: Andre Deutsch, 1958). (C) Daniel Frasnay.

carried by the work's different pictorial elements. These include the associations carried by another cluster of figures distributed across the painting, which derive from two sources that, though less celebrated than Brecht and Weill's opera, similarly explore the apparatus of the West's modern pleasure industries. If we return to the wall of photographic material with which we began (see Figure 2), we can just about make out, towards the upper right of the assemblage, the curled cover of a small book, carrying the title Nights in Paris (Figure 30). This was first published in London by Andre Deutsch in 1958, and was one of a sequence of photo-books that originated from the Bruna Press in Amsterdam. ${ }^{44}$ These offered visual tours of different cities and countries, sometimes of a decidedly titillating character. ${ }^{45}$ Though the written commentaries to these photo-books tended towards the banal, their imagery-as

${ }^{44}$ Jan Brusse, Nights in Paris, photographs by Daniel Fresnay (1958).

${ }^{45}$ Works in the series included Max Tak, This is New York, photographs by Keer Scherer (1961), Sam Waagenar, Women of Israel (1961), and Bob Bertina, Jan Blokker, Paul de Casparis \& H. J. Oolbekkink, Film Festival, photographs by Keer Scherer (1962). 


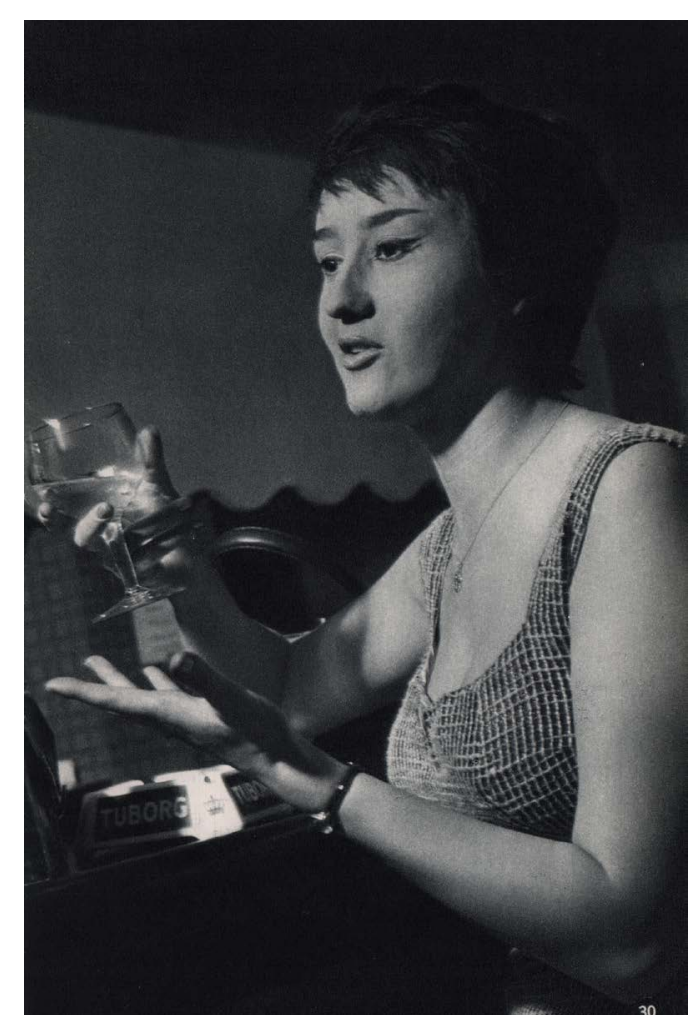

Figure 32. Daniel Frasnay, photograph in Jan Brusse, Nights in Paris, 1958 (London: Andre Deutsch, 1958). (C) Daniel Frasnay.

Andrews clearly recognised - was often of a very high order, reflecting the fact that they gave talented documentary photographers the rare chance to publish extended sequences of their work. One such figure was Daniel Frasnay, who, in Nights in Paris, provides a compelling pictorial tour through the city's cabarets, clubs, strip-joints, cafes, fairs, and restaurants. This nocturnal journey begins, of course, with the book's cover, which juxtaposes the dark silhouettes of a saxophonist and a fellow musician with a smoky view of dancers in a club; but it also includes a number of other full-page images torn out of the book by Andrews, including that of a melancholy bar-customer who holds his shadowed head in his hands (Figure 31), and who is juxtaposed not only with two glasses of absinthe but with the stark and beautiful profiles of his fellow-drinkers. If we now return to the centre of All Night Long, we will see that the artist's pictorial quotation from Brecht and Weill's Mahagonny is bracketed by those he made from this startling image of nocturnal despair, from the cover of Nights in Paris, and from another of same book's pages (Figure 32), which provided Andrews with the basis of the figure who stands next to his melancholy bar-fly.

It is becoming ever-more apparent that All Night Long is not only made up from a mass of found photographic materials, but that these materials - as in the case of The Deer Park - offered Andrews a series of overlapping perspectives on the nightlife that was his subject. The same was true of another photo-book in Andre Deutch's series, which this time focused on the 1959 Cannes Film Festival, and on the starlets, celebrities, and photographers who gathered there. Film Festival, which showcased the work of the Dutch photographer Kees Scherer, offered an illuminating and sardonic meditation on the workings of fame and publicity. ${ }^{46}$ One sequence of images and captions declares, of the festival, that:

\footnotetext{
${ }^{46}$ Bertina et al. (1962).
} 


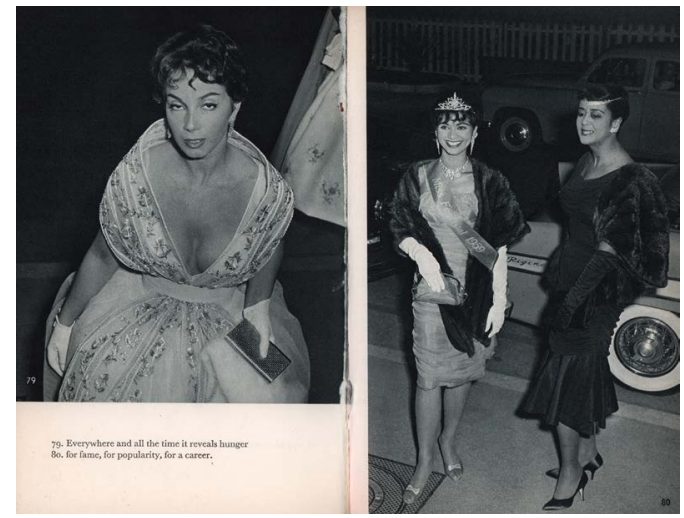

Figure 33. Keer Scherer, Double-page spread in Bob Bertina et al., Film Festival (London: Andre Deutsch, 1962). (C) Kees Scherer / Maria Austria Institute.
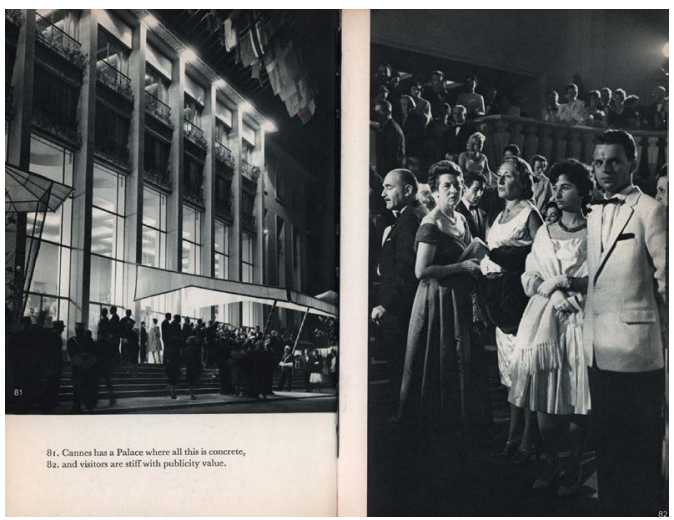

Figure 34. Keer Scherer, Double-page spread in Bob Bertina et al., Film Festival (London: Andre Deutsch, 1962). (C) Kees Scherer / Maria Austria Institute.
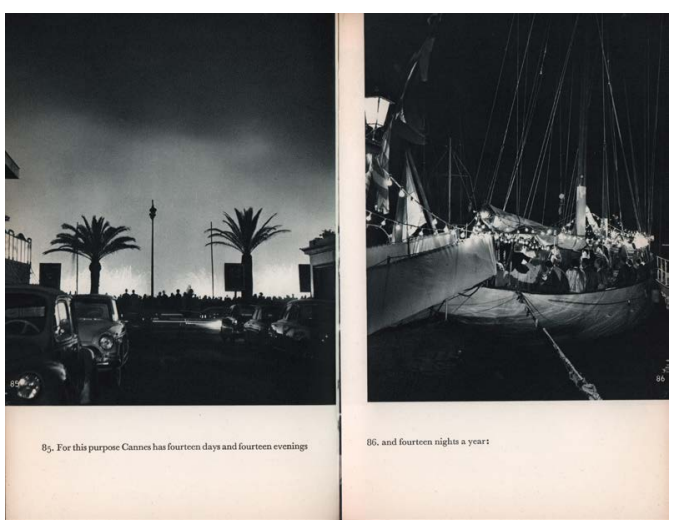

Figure 36. Keer Scherer, Double-page spread in Bob Bertina et al., Film Festival (London: Andre Deutsch, 1962). (C) Kees Scherer / Maria Austria Institute.
Everywhere and all the time it reveals hunger for fame, for popularity, for a career [Figure 33]. Cannes has a Palace where all this is concrete, and visitors are stiff with publicity value [Figure 34]. Some are young, and eager to conquer it all; some are old, and have conquered it already [Figure 35]. For this purpose, Cannes has fourteen days and fourteen evenings and fourteen nights a year [Figure 36]: and it cuts cakes, it eats slices of coffee gâteau' [Figure 37].
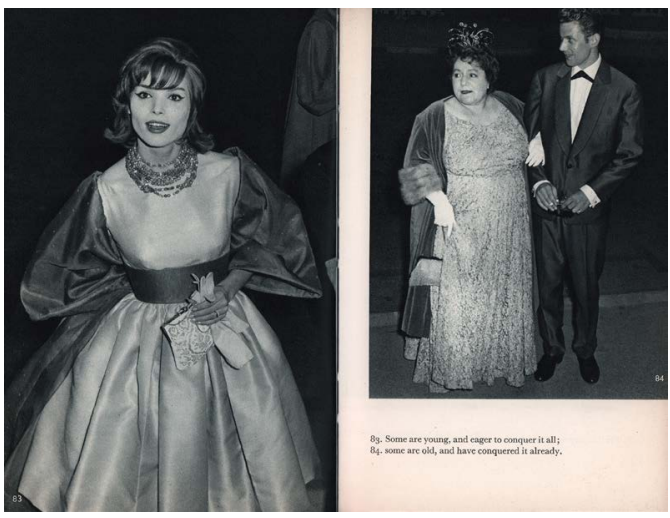

Figure 35. Keer Scherer, Double-page spread in Bob Bertina et al., Film Festival (London: Andre Deutsch, 1962). (C) Kees Scherer / Maria Austria Institute.

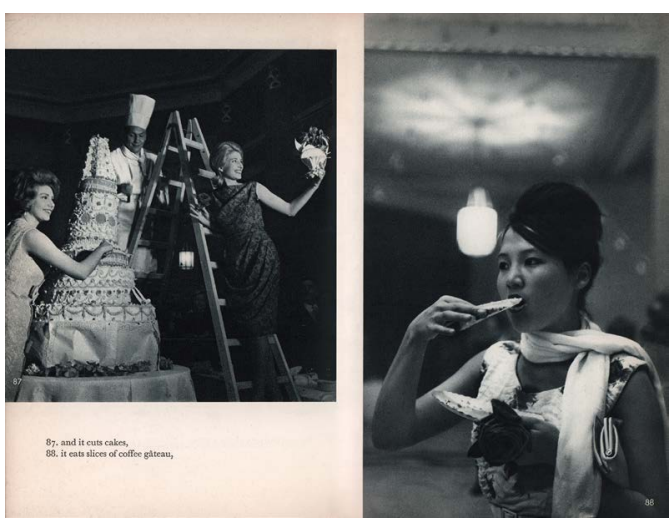

Figure 37. Keer Scherer, Double-page spread in Bob Bertina et al., Film Festival (London: Andre Deutsch, 1962). (C) Kees Scherer / Maria Austria Institute. 
Keeping this last image in mind, we can now look back at All Night Long: and there, floating over Andrews' sunbathers, we see the same figure, once again eating coffee gateau. And there, in the foreground of the central panel, and clapping her hands almost hysterically, we see another figure extracted from Scherer's pantheon of festival-goers (Figure 38). Finally, standing at the bottom of the staircase in the righthand panel, we see a version of the beautiful guitarist who, wearing Hawaiian dress, is described in Scherer's book as embodying 'the exotic' (Figure 39). Tellingly, this figure, just as in the case of her pictorial successor in All Night Long, is juxtaposed in Film Festival's pages with two women in Japanese dress, suggesting the ways in which Andrews' thinking about his new painting was shaped not only by individual images but also by the pictorial combinations he encountered on his visual explorations.

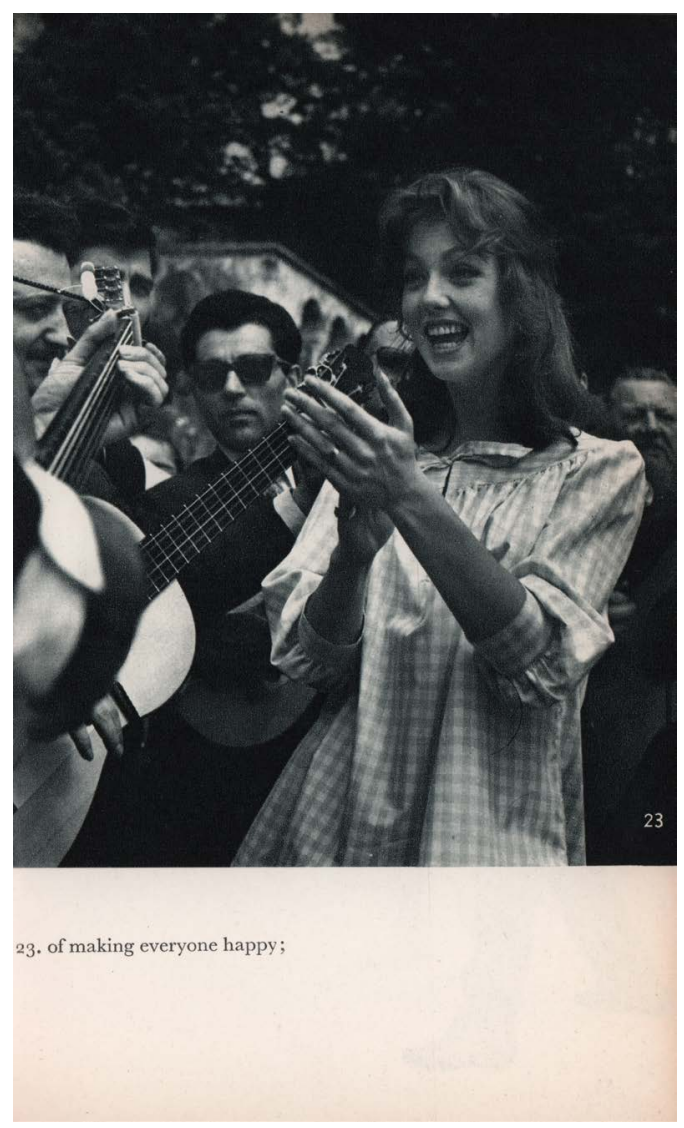

Figure 38. Keer Scherer, page in Bob Bertina et al., Film Festival (London: Andre Deutsch, 1962). (C) Kees Scherer / Maria Austria Institute.

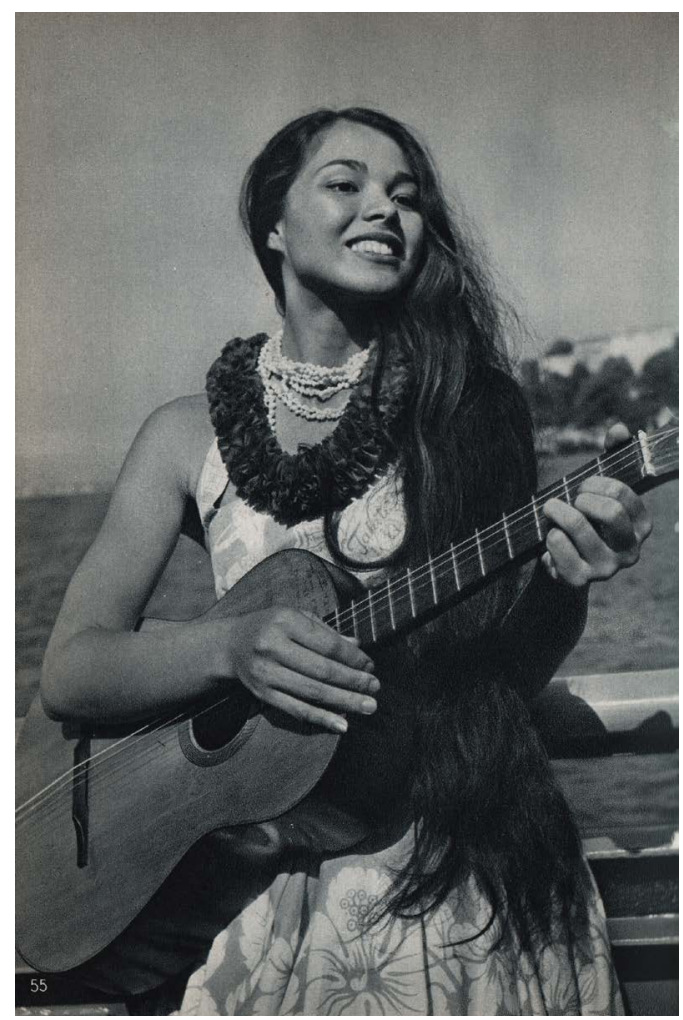

Figure 39. Keer Scherer, page in Bob Bertina et al., Film Festival (London: Andre Deutsch, 1962). (C) Kees Scherer / Maria Austria Institute. 


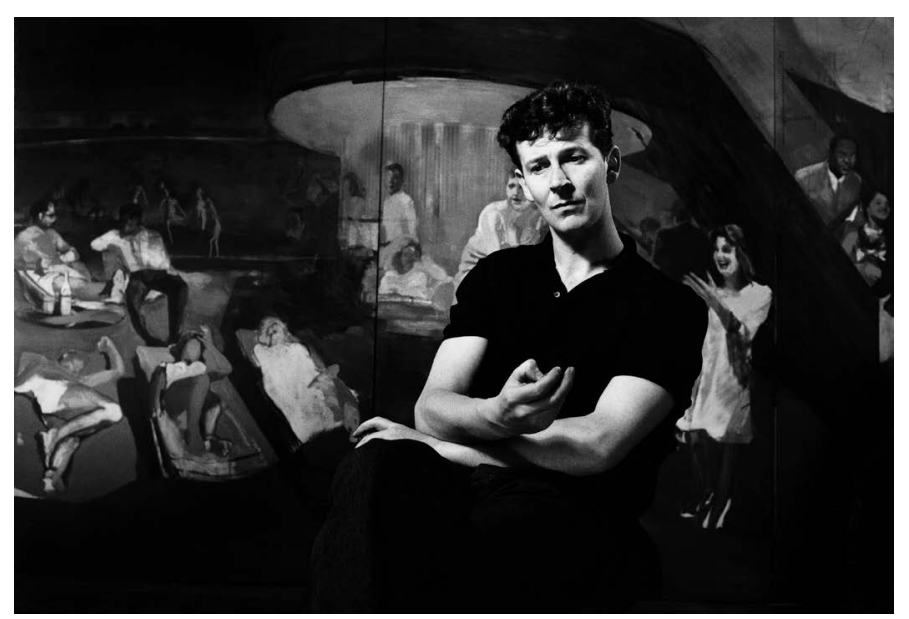

Figure 40. Jorge Lewinski, Michael Andrews, 1963, photograph. (C) The Lewinski Archive at Chatsworth / Bridgeman Images.

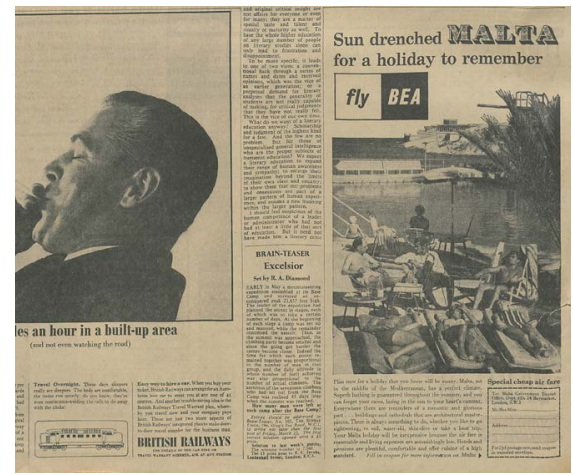

Figure 41. Detail of page from The Sunday Times, 7 March 2019. C Times Newspapers Ltd.
This interest in the forms of pictorial dialogue unearthed by his reading was complemented, on Andrews' part, by a restless experimentation with the compositional possibilities opened up by his new collage-based practice. As All Night Long developed, the artist continually toyed with different patterns of pictorial assemblage and quotation across the surface of his painting. This can be nicely demonstrated if we turn to a photograph of Andrews taken by Jorg Lewinski in August 1963 (Figure 40). By this point, as we can see, Andrews had blocked in the sunbathing figures in the foreground of his first panel, the source of which-glimpsed in Figure 2-was a British European Airways advert promoting cheap flights to Malta, which was repeatedly published in The Sunday Times in the spring of 1963 (Figure 41). ${ }^{47}$ We can also notice how the artist has begun adding the nude female swimmers whom he shows running across the background of his first panel, which he again borrowed from a newspaper photograph, this time illustrating the pleasures of a Swedish sauna party (Figure 42). ${ }^{48}$ But if we look across to the central panel, and compare it with the final painting, we can see how Andrews initially envisaged placing a rather different pair of figures in the bar-area, both of whom derive from other photographs found in his studio assemblage: one, the standing man dressed in white, is lifted from a picture that formed part of that Film Festival sequence

\footnotetext{
${ }^{47}$ See The Sunday Times, 10 February 1963, p. 26, and The Sunday Times, 17 March 1963, p. 26.

${ }^{48}$ This newspaper cutting is in the Tate Michael Andrews archive TGA 200025 3/2/1.
} 


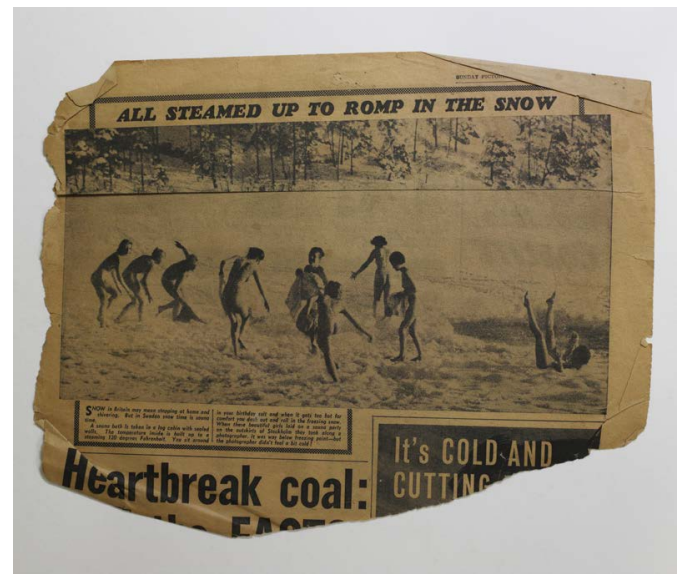

Figure 42. Newspaper clipping from Sunday Pictorial, 3 February 1963. (C) Tate archive.

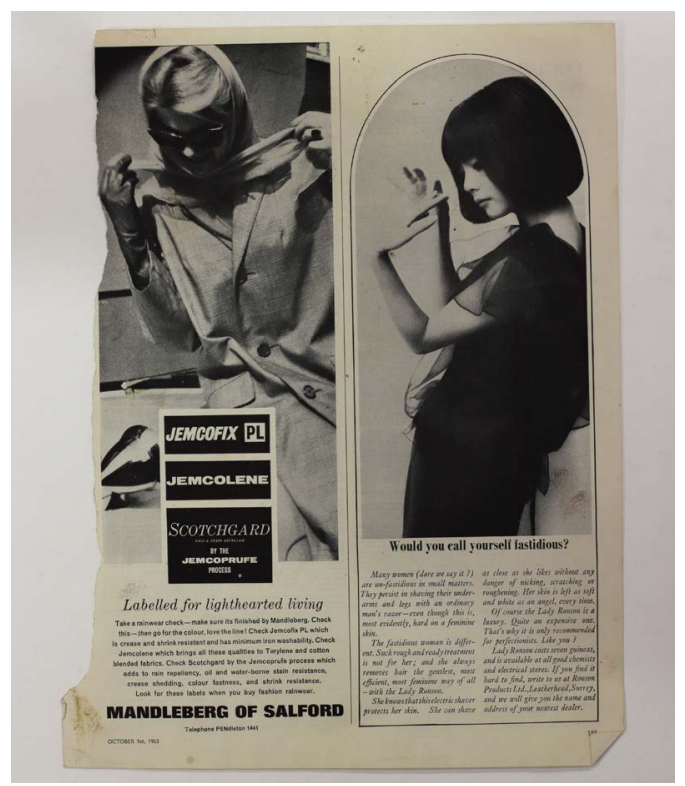

Figure 44. Page from Vogue magazine, October 1963. (C) Tate archive.

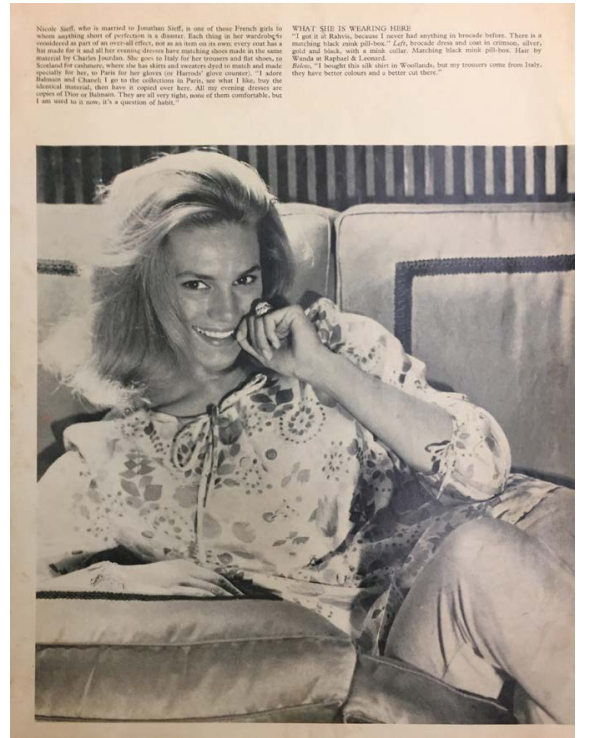

Figure 43. Unidentified magazine page, c. 1963. (C) Tate archive.

we noted earlier (see Figure 34); another, a reclining woman, is taken from a fashion magazine article on glamorous socialites, which featured someone described in the caption as 'one of those French girls to whom anything short of perfection is a disaster' (Figure 43). ${ }^{49}$ As we know, neither of these figures made the final cut; for Andrews, clearly, they both fell short of perfection. But neither, as we can also see, did the be-suited black male who initially provided a companion for the Hawaiian guitarist on the right.

If we now return to the illustration of All Night Long found in that Art and Literature issue with which the paper began (see Figure 1), we find that it, too, shows the painting in an unfinished state. This is particularly true for its upperright-hand corner. In the weeks after this

${ }^{49}$ Tate Michael Andrews Archive TGA 200025 3/2/3. 


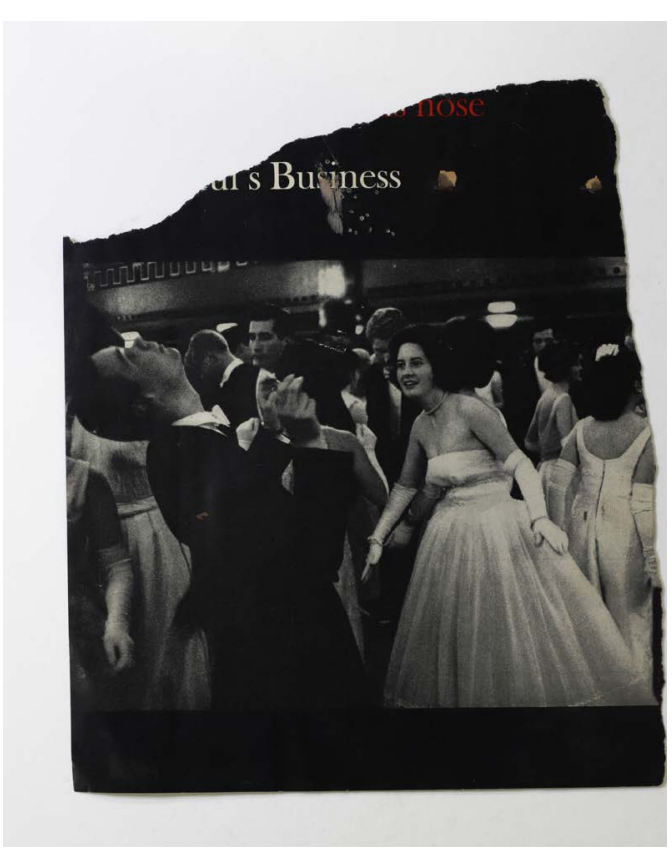

Figure 45. Fragment of page from The Sunday Times Colour Supplement, 14 July 1963. (C) Tate archive.

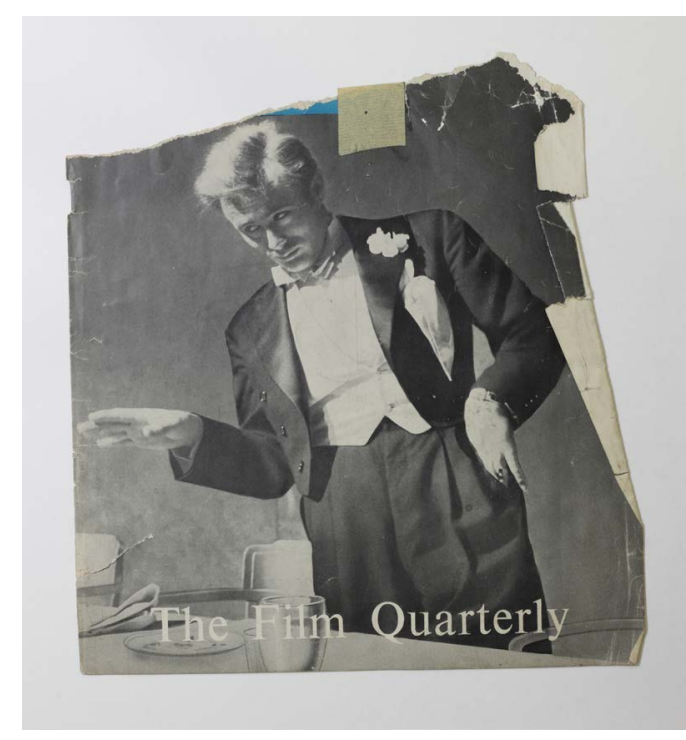

Figure 46. Fragment of cover of Sight and Sound magazine, Spring 1956. (C) Tate archive.

photograph was taken, Andrews changed the configuration of figures on the balcony, partially painting out the couple leaning over its edge, and adding both a dancing woman in black (taken from a Vogue advert for a Lady Ronson electric shaver (Figure 44) and her even more animated companion, extracted from a magazine photograph of a society ball (Figure 45). ${ }^{50}$ Andrews, at this late stage, also added two figures at the top of the stairwell: a man wearing sunglasses, whose source I have yet to identify, and a figure based on a photograph of James Dean he found on the cover of the film magazine Sight and Sound (Figure 46). ${ }^{51}$ Significantly, the photograph was a still from Dean's last film, Giant (directed by George Stevens), and shows him in a climactic scene in which, drunk, his character creates havoc at a grand family banquet.

\footnotetext{
${ }^{50}$ Both images are to be found in the Tate Michael Andrews Archive TGA 200025 3/2/1. The image of the dancing woman is taken from a feature on the University of Sussex, in The Sunday Times Colour Section, 14 July 1963, p. 22. The advert from Vogue appears on page 185 of the October 1963 issue.

${ }^{51}$ Tate Michael Andrews Archive TGA 200025 3/2/1. The photograph of Dean comes from the cover of Sight and Sound, Spring, 1956. The same issue carried a review of the film Together (directed by Lorenza Mazzetti), in which Andrews had starred alongside Eduardo Paolozzi.
} 


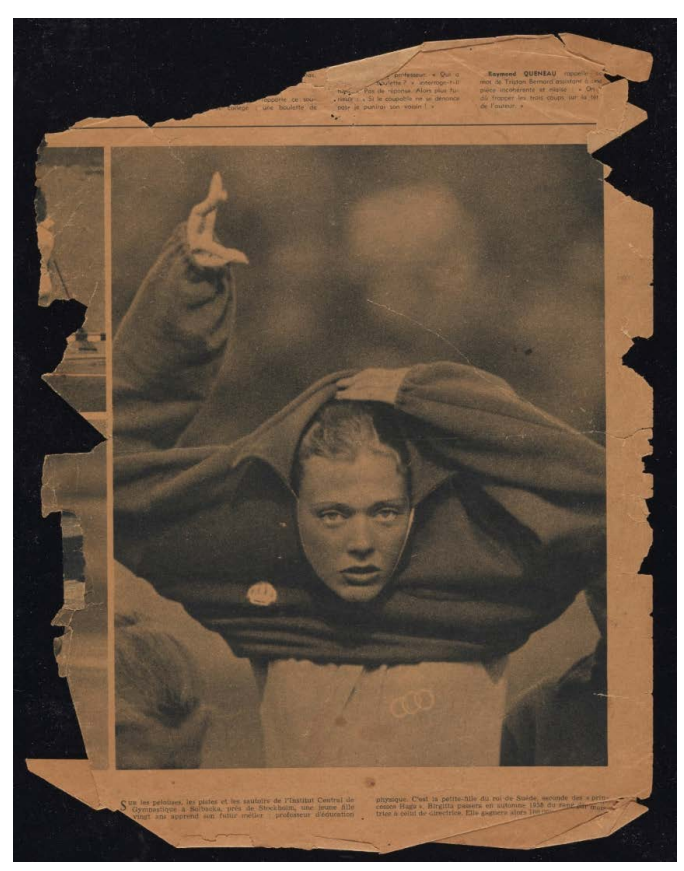

Figure 47. Clipping from unidentified newspaper page, 1958. (C) Tate archive.

It has become abundantly clear that All Night Long is built up from a dizzying array of pictorial motifs, which, like a collagist working with scissors, paper, and glue, Andrews would continually reshuffle and overlay, and which he would sometimes take out of the final image altogether. The picture, from this perspective, can easily be read as a painted equivalent to the assemblage from which it was made: that is, as a surface onto which details such as the intriguing figure on the left, pulling a sweater over her head-which is taken from a magazine photograph of Princess Birgitta of Sweden, competing in a 1958 gymnastics tournament (Figure 47) are overlaid, or moved around, one after the other, just as in the case of the photographs distributed by the artist across his studio wall..$^{52}$ This is painting as pinboard.

Similarly, All Night Long can be interpreted, like The Deer Park, as a painting that borrows not only its subject-matter, but even its formal techniques, from the world of contemporary cinema. Some of the critical writings on the painting have suggested precisely this: thus, Michael McNay has declared that All Night Long's 'photo-realism and compositional jump-cuts are clearly cinematic', and Richard Cork has described it a 'near-cinematic work'. ${ }^{53}$ And they have a point, particularly when we realise that the painting's title — chosen quite late in the day — gestures to Basil Dearden's film All Night Long (Figure 48), ${ }^{54}$ a loose updating of Othello which was released in 1962, and which, tellingly, focuses on the conspiratorial narratives of a London nightclub. The film is set almost entirely in the box-like space of the club itself, which is once again split into two levels, connected by a stairwell that becomes one of the story's main structural devices. Andrews seems to offer up his own picture as a painted counterpart to Deardon's similarly boxed-in, split-level cinematic world; but to my eyes, his

\footnotetext{
${ }^{52}$ Tate Michael Andrews Archive TGA 200025 3/2/3.

${ }^{53}$ Michael McNay, The Guardian, 29 November 1980; Richard Cork, The Times, 14 July 2001.

${ }^{54}$ See https://www.youtube.com/watch?v=KoqZK-UzlpU. This link to Dearden's film has also been suggested by Robin Simon; see Ben Tufnell (2001: 91, f. 1.).
} 


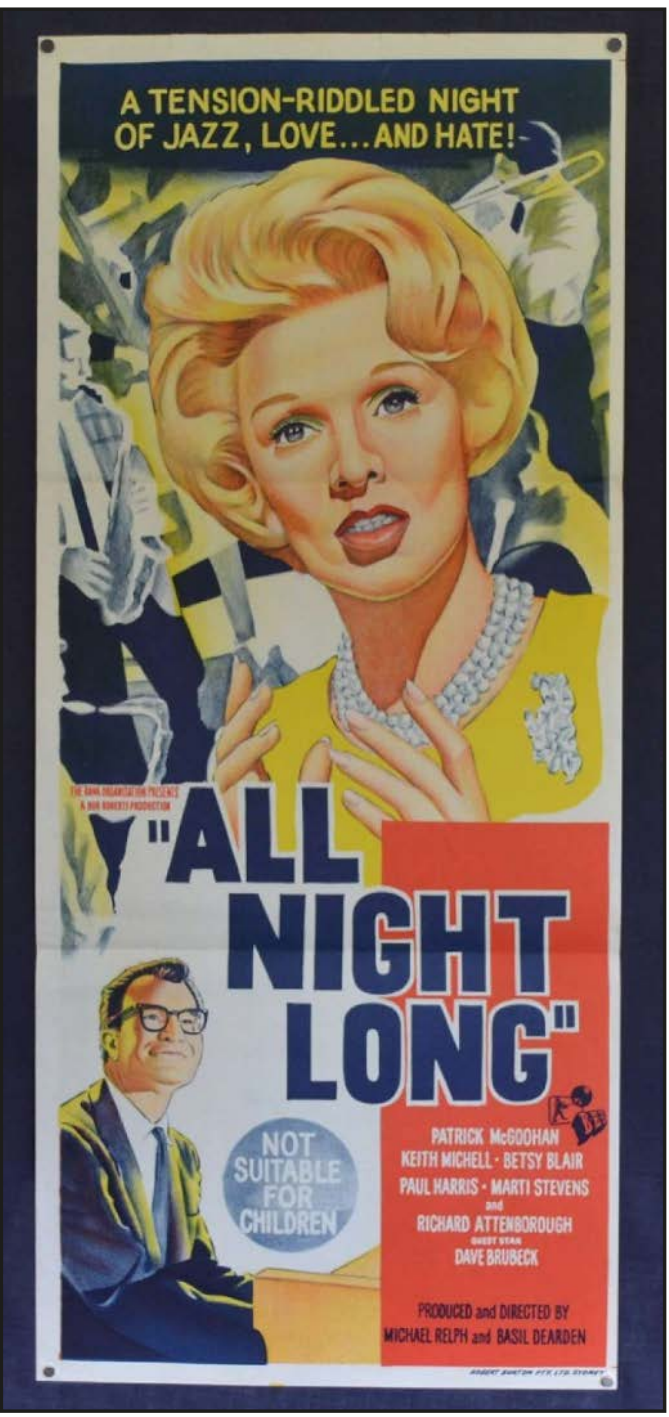

Figure 48. Poster for All Night Long directed by Basil Dearden, 1962.

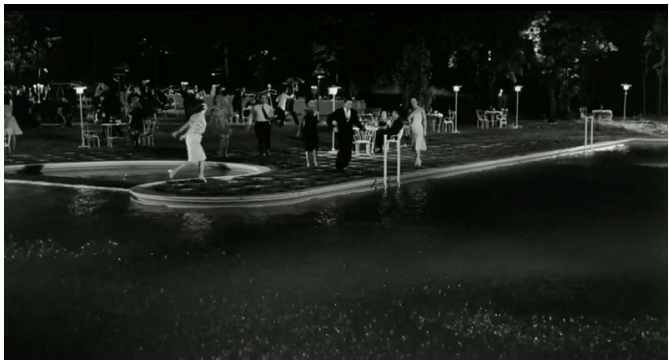

Figure 49. Film still from La Notte directed by Michelangelo Antonioni, 1961. (C) Nepi Film / Sofitedip / Silver Films.

painting is still shaped, and shaped far more powerfully, by that other cinematic chronicle of the night, Antonioni's $\mathrm{La}$ Notte, and by the shifts of moods, perspective, and imagery found in its scenes of nocturnal revelry. In one of these scenes, just as in the background of All Night Long, party-goers throw themselves into a pool with wild abandon (Figure 49). ${ }^{55}$ Such sequences take us right to the heart of the desperate hedonism that, Andrews, too, sought to capture in his picture.

Even as Andrews courts these references to photographic assemblage and to film, he also, finally, asserts the materials and techniques of painting itself. Significantly, All Night Long took him more than a year to complete, which tells of the fact that the more 'level-headed' approach he adopted after his rapid-fire experiment with Deer Park saw him returning to some of his older habits of work. Most interestingly of all, he began once more to paint from the living model. In the spring of 1963, Andrews had begun what was to become a lifelong relationship with June Keeley, whose own previous experience as a nightclub hostess offered him yet another insight into the world he was so interested in depicting. Over the course of that year, he repeatedly asked Keeley to model for some of the figures in All Night Long, and, in doing so, to adopt precisely the poses

\footnotetext{
${ }^{55}$ See https://www.youtube.com/watch?v=JHdYmUfoF6k (1.22.40-1.23.29).
} 
found in the photographs from which those figures originated.$^{56}$ This rather remarkable request saw his new girlfriend, as Keeley still remembers vividly, posing for the woman who applauds at the centre of the painting; for the woman crouched over the falling man; and for the central figure in the group of sunbathers on the left. These sessions, the last of which generated a separate study of Keely that Andrews was to rework and sell at the end of the decade (Figure 50), were intended, no doubt, to help the artist flesh out and complete figures for whom his photographic sources provided too little visual information. As such, they signalled a return on his part not just to the very specific kinds of life-painting encouraged by Coldstream at the Slade, but also to a more general and traditional sense of painting as a practice shaped by the encounter with the living rather than the photographic model.

Recovering the story of these modelling sessions seems to pull Andrews' work away from the realm of the photographic and the cinematic, and return it more forcibly to that of painting. So, too, does a closer look at the way in which the artist actually translates his photographic sources into paint: over and over again, and, no doubt emboldened by the example of artists such as Bacon, Andrews seems concerned to create a critical distance between his pictorial language and those of his visual sources, even as he happily signalled his reliance on those sources. Just look, for instance, at the way he adapts that old Japanese photograph we saw earlier, which he

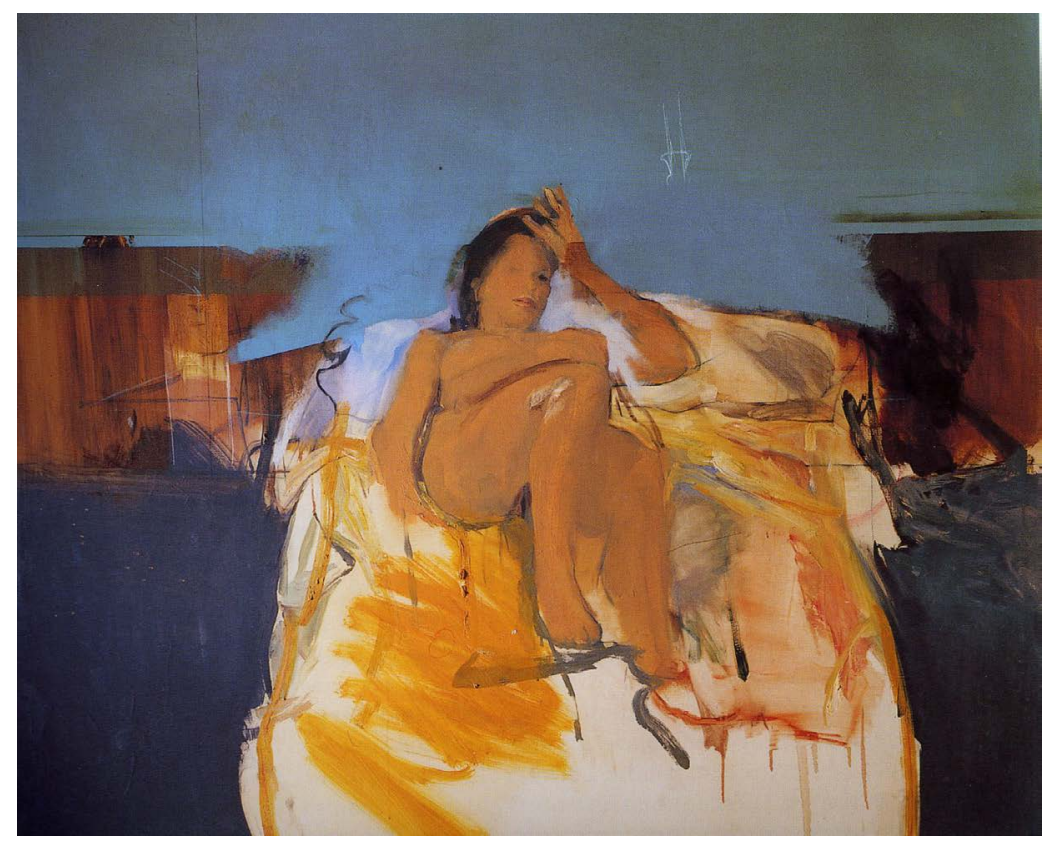

Figure 50. Michael Andrews, Portrait of J. K., 1963 and 1968-9, oil on canvas, $150 \times 183 \mathrm{~cm}$ C The estate of Michael Andrews.

${ }^{56}$ June Keeley, in conversation with the author, 7 May 2019. 


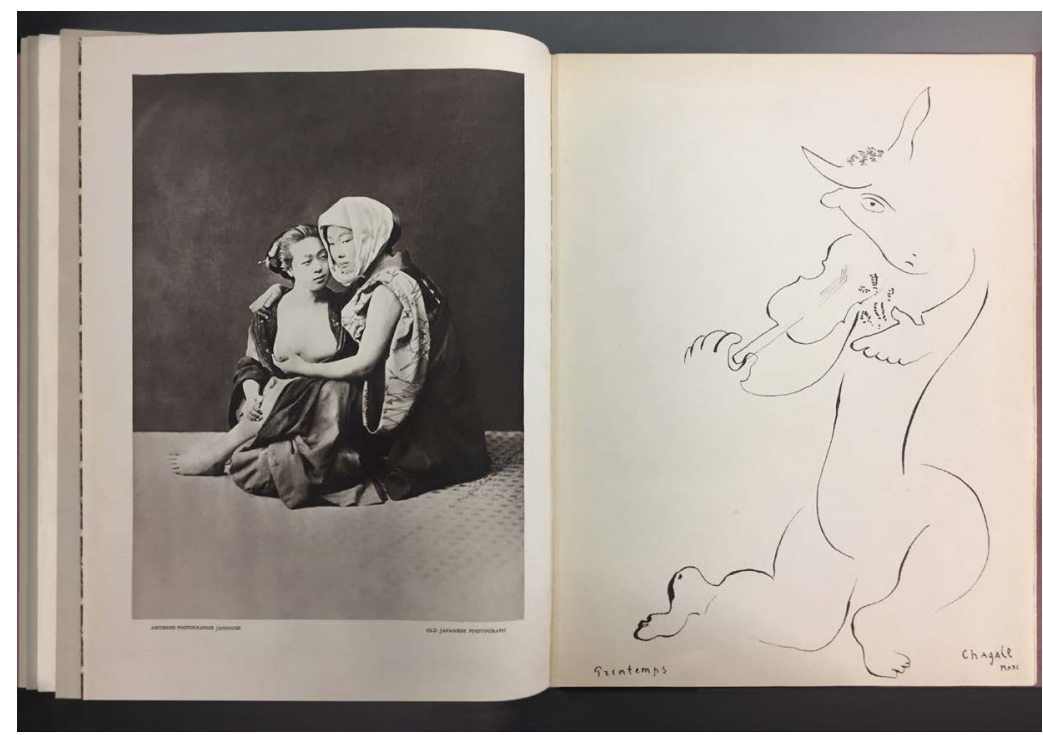

Figure 51. Double-page spread in Verve magazine, Paris, 1938 C Verve Magazine.

had cut out of a 1938 issue of Verve, a leading modernist magazine published in Paris. ${ }^{57}$ There (Figure 51), the two pictured women had been visually paired with a Chagall image of yet another musician, and absorbed into a heavily eroticised iconography of what the magazine called the 'Orient', which incorporated an ancient photograph of a travelling harem and a painted Odalisque by Matisse. Andrews turns their subdued, subjugated figures into an enigmatic pictorial hieroglyph that is

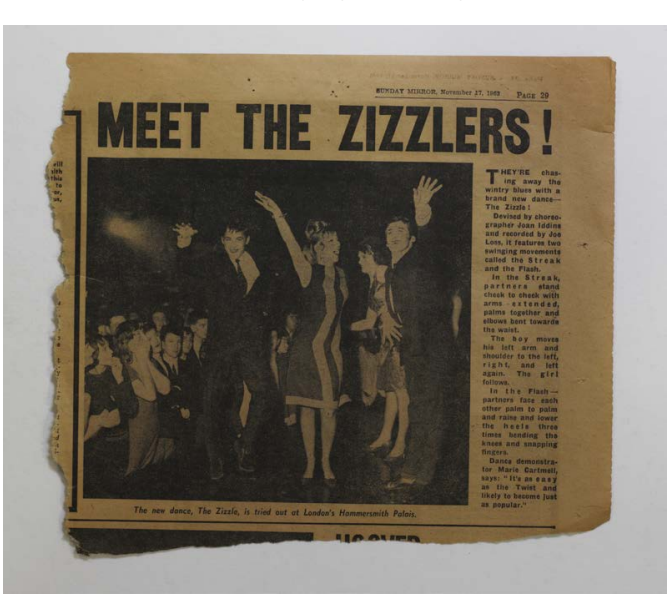

Figure 52. Newspaper clipping from The Sunday Mirror, 27 November 1963. (C) Tate archive. intended, perhaps, to signify an alluring but troubled final phase of the night. In doing so, crucially, he effaces not only the features of the two women themselves, but many of the signs of the medium in which they were pictured; we confront not so much the painted twin of a 19th-century photograph, but a more distant pictorial relative, constructed out of a raw mesh of exposed black brushstrokes and gauze-like veils of colour. And it takes only a few seconds to see that this kind of push and pull between Andrews' painted imagery and its photographic sources is

${ }^{57}$ Verve, Volume 1, Number 3 (Oct-Dec 1938) (Paris). 
characteristic of All Night Long as a whole. All of its details - the clapping woman, whose face is newly blotched and striated, and whose dress is transformed into a swathe of dragged brushstrokes; the clutch of sunbathers, whose bodies become a succession of patchwork holograms; even the two distant, gesturing party-goers, taken from a newspaper story on an ephemeral dance craze called the Zizzle (Figure 52) - who are recast as a flash of limbs and a flicker of red and black against the deep blue of the pool - all remain highly dependent on the kinds of pictorial sources that I have been unearthing in this paper; at the very same time, however, they all claim for themselves a new, semi-independent painterly existence. ${ }^{58}$

\section{VI}

Excavating the ways in which Deer Park and All Night Long were put together has served, I trust, to suggest the ways they were works that deliberately trespassed the boundaries between different artistic forms, and that took the dynamics of pictorial collage in exciting new directions. They are also, I would argue, works in which Andrews sought to weave the visual fabric of contemporary life into the traditional conventions of history painting, and in which the seemingly superficial subject of the modern party is used as a prism through which to investigate and expose the myths, aspirations, and tragedies of the Affluent Society, and to evoke older forms of hedonism and breakdown. An even fuller account of how they address these larger tasks would require another, or a longer paper; but such an account could well take as its own starting point two early passages of criticism written in response to Andrews' works by David Sylvester and John Russell, with which I will end.

Sylvester, writing in early 1963 of Andrews' party paintings, declares that 'these paintings are about pleasure and sometimes about glamour, but only in the sense that a story by Scott Fitzgerald is: the play is haunted, perhaps above all by doubt' ${ }^{59}$

Meanwhile, Russell, writing in 1965, declares that both Deer Park and All Night Long aspire to offer what he calls 'a panorama of modern life'. He then outlines what he thinks are their core concerns: 'What is going on', he says, 'has elements of orgy, elements of nightmare, elements of a stylised 'good time', and elements of fugitive deep feeling. If these pictures are about anything, they are about the contrast between

\footnotetext{
${ }^{58}$ The photograph of the new dance craze is to be found in Tate Michael Andrews Archive TGA 200025 $3 / 2 / 1$.

${ }^{59}$ David Sylvester 'Michael Andrews: "mysterious conventionality", , Sunday Times Colour Section, 13 January 1963, p. 15.
} 
the shoddy machinery of pleasure, the collective apparatus of excitement, and the separateness in which the individual proceeds towards disintegration. ${ }^{60}$

Sylvester and Russell brilliantly illuminate some of the deeper preoccupations of Andrews' two paintings; my hope is that I, in turn, have illuminated the extraordinary variety of these pictures' ingredients and the deceptive intricacy of their construction.

Acknowledgements: For all their support in helping me to get to know Andrews' work, I would like to thank his widow June and his daughter Mel. I would also like to thank Rosie Ram, David Solkin, Allison McNeill, Jan Schubert, James Hyman, Catharine Lampert, Maisoon Rehani, and all those who have catalogued his remarkable archive at Tate Britain, from which I drew heavily in my lecture. The most comprehensive accounts of the artist's work and career are to be found in a succession of impressive exhibition catalogues: Catherine Lampert (ed.), Michael Andrews (London, Arts Council, 1980); William Feaver and Paul Moorhouse, Michael Andrews (London, Tate Publishing, 2001); and Richard Calvocoressi, Michael Andrews: Earth, Air, Water (London, Gagosian, 2017).

\section{REFERENCES}

Andrews, Michael \& Willing, Victor (1964), 'Morality and the Model', Art and Literature: An International Review, Summer: 49-64.

Bertina, Bob, Blokker, Jan, de Casparis, Paul \& Oolbekkink, H. J. (1962), Film Festival, photographs by Keer Scherer (London, Andre Deutsch).

Calvocoressi, Richard (2017) Michael Andrews: Earth, Air, Water (London, Gagosian).

Corbett, David Peters (2001), Walter Sickert (London, Tate Publishing).

Feaver, William \& Moorhouse, Paul (2001), Michael Andrews (London, Tate Publishing).

Galbraith, John Kenneth (1958), The Affluent Society (Boston, MA, Houghton Mifflin).

Giles, Steve (ed. and trans.) (2007), Bertolt Brecht, Rise and Fall of the City of Mahagonny (London, Bloomsbury).

Harrison, Martin (2005), In Camera-Francis Bacon: Photography, Film and the Practice of Painting (London, Thames and Hudson).

Lampert, Catherine (ed.) (1980), Michael Andrews (London, Arts Council).

Mailer, Norman (1955), The Deer Park (New York, G. P. Putman's Sons).

Mailer, Norman (1957), The Deer Park (London, Allan Wingate).

Mailer, Norman (1962), The Deer Park, Corgi Paperback edn (London, Penguin).

Robertson, Bryan, Russell, John \& Lord Snowdon (1965), Private View (Thomas Nelson, London).

Russell, John (1962), 'Pioneer of Pop Art (People of the 60s)', The Sunday Times Colour Section, 4 February: 16-17.

${ }^{60}$ John Russell (in Robertson et al. (1965), Private View: 262). 
Sylvester, David (1963), 'Michael Andrews: “mysterious conventionality”', Sunday Times Colour Section, 13 January: 15.

Tufnell, Ben (2001), 'Illuminations: Michael Andrews, Mailer and Rimbaud', The British Art Journal, 2(3, Spring/Summer): 88-91.

To cite the article: Mark Hallett (2020), 'The newspaper man: Michael Andrews and the art of painted collage', Journal of the British Academy, 8: 105-140.

DOI https://doi.org/10.5871/jba/008.105

Journal of the British Academy (ISSN 2052-7217) is published by The British Academy, 10-11 Carlton House Terrace, London, SW1Y 5AH

www.thebritishacademy.ac.uk 